\title{
4 Gynecological Theory in Arabo-Galenic Medicine
}

\section{The importance of the Greco-Roman medical tradition in Arabic medicine}

In his Shukūk 'alā Jālīnūs (Doubts About Galen) the famously independent physician Abū Bakr Muḥammad ibn Zakarīyā al-Rāzī (d. 311/923), known as Rhazes in the Latin tradition, writes:

\begin{abstract}
Galen says, "One who understands what is said in this section knows what renders men sterile and women infertile: that is, a man who has a balanced temperament is always fertile, but one who lacks balance will be fertile if he so happens to be coupled with his opposite in humoral temperament.” This is not true, for I have seen many men such as this, cycling through women, hoping to reproduce, and it is of no use to them. One of them would buy slave girls according to our guidance to him, and I evaluated their humoral compatibility with him. ${ }^{304}$ I also had a neighbor, whose warm and moist temperament could pass for that of a camel, who expended great efforts in his cycling through slave girls, but it was of no use to him - even though Galen says that this sort of temperament is strongest with respect to reproduction. ${ }^{305}$
\end{abstract}

Al-Rāzī’s observations remind us of some peculiar aspects of infertility as an "illness." First, it was ongoing, and therefore a patient usually had the time to make a variety of attempts to fix the problem. This was not true of other types of ailments such as acute diseases or injuries. However, infertility was anomalous among other long-term conditions such as chronic pain, or diminished eyesight, in that there was a strong possibility that it could be resolved. Like fevers and other acute conditions, infertility could pass, whether due to effective intervention or despite neglect or harmful medical treatment. If it resolved and the former sufferer did produce children, having had ample time to attempt a variety of treatments, attributing the source of healing was a matter open to interpreta-

304 The Christian physician, Ishāq ibn 'Alī al-Ruhāwī (d. 931 A.D.), who lived in northwestern Iraq, seems to allude to the practice of physicians choosing sexual partners for their patients when he writes, "It is of value to distinguish between skillful shrewd practitioners and those who imitate them. You may see these two classes when they come into a city and plan to show what they claim about their work with various arts. Some of them butter up the sultan of that country with electuaries and in selecting women who are pretty and act well, which they claim have [health] value.” This translation of al-Ruhāwì’s Adab al-țabīb is from Martin Levey, "Medical Ethics of Medieval Islam with Special Reference to Al-Ruhāwī's 'Practical Ethics of the Physician,"” Transactions of the American Philosophical Society 57 (1967), 90.

305 al-Rāzī, Kitāb Shukūk 'alā Jālīnūs (Tehran: Mu'assasah-'i Muțāla'āt-i Islāmī, Dānishgāh-i Tihrān, 1993), 79.

Ә OpenAccess. (C) 2020 Sara Verskin, published by De Gruyter. (cc))BY-NC-ND This work is licensed under the Creative Commons Attribution-NonCommercial-NoDerivatives 4.0 License. 
tion. Moreover, unlike most other types of long-term medical conditions, there was a clear line differentiating between success and the lack thereof in treating infertility. In the management and alleviation of pain, or even diminished eyesight, the patient's subjective perceptions dictated the extent to which a course of treatment was deemed successful. Not so for the treatment of infertility. When successful treatment was marked by the arrival of a child, one could make an empirical argument, or at least an anecdotal one, demonstrating the failure of a particular explanatory theory and course of treatment, which is precisely what al-Rāzī does.

Al-Rāzì's attack on Galen's statements about fertility respond to a medical culture which proudly described its theories as an intellectual inheritance from the Greco-Roman world. Hippocrates (fl. c. $5^{\text {th }}$ century B.C.), Aristotle (fl. c. $4^{\text {th }}$ century B.C.), Dioscorides (fl. c. $1^{\text {st }}$ century A.D.), Galen (d. c. 216 A.D.), Paul of Aegina (fl. c. $7^{\text {th }}$ century A.D.) and many others are cited as authorities in the medieval Arabic gynecological literature. Most of the gynecological beliefs described below entered into the Arabic medical corpus through the mediation of Galen and later figures such as Stephanus of Athens, Aetius of Amida, and Paul of Aegina. ${ }^{306}$ It is not my intention to explore here the translation and reception history of individual Greek or Roman medical texts, or to trace the route through which they were transmitted to the Arabic-writing world, since others have already done so. ${ }^{307}$ Instead, this chapter explores the substance of

306 For the importance of Galen in shaping the Arabic reception of Hippocratic texts, see M. Ullmann, Die Medizin im Islam (Leiden: Brill, 1970), 35-62; N. Fancy, "Womb Heat versus Sperm Heat: Hippocrates against Galen and Ibn Sīnā in Ibn al-Nafīs's Commentaries,” Oriens 45 (2017), 150 - 175; and P. Pormann, "The Hippocratic Aphorisms in the Arabic Medical Tradition," Aspetar 2 (2013), 412- 415.

307 There are several scholarly works which describe the transmission of Greco-Roman gynecology to the medieval Islamic world and to Latin Europe. Max Meyerhof and Dimitri Joannides produced three short monographs on the subject in the 1930s. D. Joannides, Esquisse de la gynécologie et de l'obstétrique chez les égyptiens et les grecs (Cairo, 1934); idem, La gynécologie et l'obstétrique chez Avicenne (Ibn Sina) et leurs rapports avec celles des grecs (Cairo, 1938); and idem, La gynécologie et obstétrique de Paul d'Egine et son influence sur la médecine arabe (Cairo, 1940). Ursula Weisser wrote an important study of medieval Arabic understandings of the physiology of reproduction and heredity Zeugung, Vererbung, und pränatale Entwicklung in der arabisch-islamischen Mittelalters. Monica Green's “The Transmission of Ancient Theories of Female Physiology and Disease Through the Early Middle Ages” (Ph.D. Dissertation: Princeton University, 1985) provides the best overview of the history of the translation movement with respect to gynecology. It includes an appendix with useful flowcharts depicting the translation movement with regard to individual gynecological texts on pp. 235-238. For a recent philologically-oriented analysis of the transmission, reception, and exegesis of Hippocratic aphorisms pertaining to gynecology see Rosalind Batten, “The Arabic Commentaries On The Hippocratic 
Arabic medical writings about the causes and treatments of infertility and related gynecological issues.

This book uses "Arabo-Galenic medicine” as an infelicitous shorthand for a complex intellectual heritage as we know it from a certain set of highly influential texts which routinely refer to each other. These texts are all written in Arabic, though many of the texts' authors were also steeped in other linguistic traditions. Some of these texts reflect a variety of sources of local and global medical knowledge, especially Indian medicine and particularly Indian pharmacy, although this influence and inspiration is sometimes acknowledged only in vague or anonymizing terms by our authors. Most often, the medieval authors explicitly situate their own thinking and contributions to the medical field in the context of Greek thought, especially as mediated by Galen and Galen's disciples. They buttress their arguments by citing either texts translated from the original Greek and Syriac into Arabic, or by engaging with other original Arabic texts which also situate themselves within the same intellectual heritage.

As depicted by the medieval Arabo-Galenic authors themselves, the ancient theorists who exerted the most influence on their own framework for understanding gynecology were Hippocrates, Aristotle, and Galen. ${ }^{308}$ Whereas in the medieval Latin world Soranus's (fl. c. 100 A.D.) famed Gynecology was continuously in circulation, there is little evidence that it was ever translated into Arabic. However, some of Soranus' gynecological thought became known to the Arabic world through Paul of Aegina (d. c. 690 A.D.). ${ }^{309}$ The gynecological sections of many of the Byzantine medical encyclopedias, which were later transmitted to the Arabic world, also draw heavily on Soranus' treatments.

The extant Hippocratic treatises relating to gynecology are Diseases of Women (I \& II), Diseases of Young Girls, On Barrenness, Generation and Nature of the Child, Nature of Women, Seven-month Child, Eight-Month Child, Superfetation and Excision of the Embryo. According to Manfred Ullmann, only two of the more minor works on gynecology, Superfetation and Diseases of Young Girls, are known to have been translated into Arabic in the medieval period, as was Hip-

Aphorisms: Arabic Learned Medical Discourse On Women's Bodies (9th-15th Cent.)” (Ph.D. Dissertation: University of Manchester, 2018). Scholarly discussions about which Greek gynecological works were available in Arabic versions has heavily relied on the work of Manfred Ullmann. Ullmann's Die Medizin im Islam is available in an accessible English summary: Islamic Medicine (Edinburgh: Edinburgh University Press, 1978).

308 Weisser, Zeugung, Vererbung, und pränatale Entwicklung, 53.

309 Ullmann, Islamic Medicine, 11, 14, 15 and Peter Pormann, The Oriental Tradition of Paul of Aegina’s Pragmateia (Leiden: Brill, 2004). 
pocrates' Aphorisms, which also includes gynecological material. ${ }^{310}$ On Generation and Nature of the Child also exists in a modified form in Arabic as Kitāb al-ajinna li-Buqrāt. ${ }^{311}$ A book attributed to Hippocrates called Kitāb awjā' alnisā', i.e. "Diseases of Women," is found in lists of books but, according to Ullmann, there is no evidence that it was ever extant in Arabic. ${ }^{312}$ However, Superfetation has a broader gynecological scope than its title implies, corresponds closely with Diseases of Women I, and contains some passages which are identical to those found in On Barrenness. Of all of these, Hippocrates' Aphorisms is the most frequently cited text in the medieval Arabic medical literature pertaining to infertility.

Medieval gynecology, like other branches of medicine, was heavily influenced by Galenic thought. ${ }^{313}$ The authority of Galen was so respected that a medieval physician might resort to ta'wīl (scriptural reinterpretation) in order to explain away his errors by arguing that his teachings had merely been misunderstood. Johann Christoph Bürgel notes the following example of such esteem:

'Abd al-Laṭif al-Baghdādī discovered that the lower jawbone of the human body was not, as Galen had thought, composed of two parts, but that it was a single sutureless bone. This famous Egyptian scholar made his discovery in the course of osteological studies in an ancient cemetery in the northwest of Cairo - but not until he had investigated more than two thousand skulls did he realize that he had come across an error in Galen's teaching. In his account of this experience he expressed the conviction - which, self-evident as it may seem to us, was a bold statement in those times - that the evidence of the perception of our senses deserved more confidence that the teachings of Galen; ${ }^{314}$ though having said so,

310 Green, "The Transmission of Ancient Theories of Female Physiology and Disease Through the Early Middle Ages," 79 and Ullmann, Die Medizin im Islam, 29.

311 Commenting on the relationship between the two texts, the modern editors of Kitāb al-ajinna li-Buqrāt write: "The text, as preserved ... shows a mixture of translation, paraphrase, and comment . . . in many cases the distinctions between expanded translation, paraphrase and restatement are blurred.” M. C. Lyons and J. N. Mattock, Kitāb al-ajinna li-Buqrāt (Cambridge: Pembroke Arabic Texts, 1978), ii.

312 M. Ullmann, “Zwei spätantike Kommentare zu der hippokratischen Schrift 'De morbis muliebribus”" Medizinhistorisches Journal 12 (1977), 245-262; M. Green, “The Transmission of Ancient Theories of Female Physiology and Disease through the early Middle Ages," 74.

313 Green, "The Transmission of Ancient Theories of Female Physiology," 235-7.

314 Al-Baghdādī’s claims to originality were by no means well-received. See N. Peter Joosse, The Physician as a Rebellious Intellectual: The Book of the Two Pieces of Advice or Kitāb al-Nașịhatayn by 'Abd al-Lațîf ibn Yūsuf al-Baghdādī (Frankfurt am Main: Peter Lang Edition, 2014). The biographer Ibn al-Qiftī's entry about him is both personally and professionally scathing. It concludes, "In 628, it occurred to him to travel to Iraq and to make the hajj pilgrimage. He fell sick in Baghdad and began to treat himself with his own medicine, and died - just as 
he added, typically enough that there might be found an interpretation of the words in question which would free Galen from the charge of error. ${ }^{315}$

A somewhat less diffident attitude can be found in the above-quoted Shukūk 'alā Jālīnūs (Doubts About Galen) in which al-Rāzī anticipates that his criticism of Galen, and in particular of his humoral theory, will itself be met with consternation. Using terminology that is deliberately reminiscent of Islamic jurisprudential language, al-Rāzì compares the stance of his critics, who believe he should have a more reverential attitude toward Galen, to jurists bound by taqlid. Taqlid refers to the intellectual posture of a jurist who imitates or conforms to his predecessors' conclusions, rather than revisiting the premises on which they are based, due to his belief that he is bound by his predecessors' authority. Al-Rāzì instead calls on his fellow scientists to emulate the sunna, the exemplary tradition, of the great philosophers of old. His language echoes the religious value of emulating the sunna of the Prophet Muhammad.

As for those who censure me and call me ignorant for having produced this Book of Doubts - I do not call them philosophers. They have turned their backs on the tradition (sunna) of the philosophers. They have taken up the tradition of ignorant upstarts, through imitation (taqlid), refraining from raising any objection against it. Aristotle says: 'Plato and the Truth are at odds, and both are friends to me - but the Truth is a friend dearer still than Plato., ${ }^{316}$

Al-Rāzì's criticisms of Galen's theories were indeed alarming enough to inspire some of the great figures of medieval medicine such as Ibn Abī Șādiq alNissābūrī (d. after 462/1068), Ibn Zuhr (Avenzoar, d. 557/1162) and Moses Maimonides (d. c. 1204) to write refutations of them. Ibn Zuhr accounted for this failing in al-Rāzì by claiming that either al-Rāzì did not author the book at all, or he wrote his book when he was an adolescent too young to understand Galen, or

God had wished - in the year 629. His books were sold in Aleppo. I happened upon some of them, and they were of the degree of inferiority which is furthest removed from perfection. God save us from the enticement of pretentiousness!” Ibn al-Qiftī, Inbāh al-ruwāt 'alā anbāh al-nuḥāt, ed. Muḥammad Ibrāhīm (Cairo: Dār al-Kutub al-Mișriyya, 1950), 2:196. Translation by A. Verskin, "A Muslim-Jewish Friendship in the Medieval Mediterranean: 'Alī Ibn al-Qifțīs Biography of Rabbi Yūsuf Ibn Sham'ūn," in The Idea of the Mediterranean, ed. Mario Mignone (Stony Brook: Forum Italicum Publishing, 2017), 189.

315 J. C. Bürgel, "Secular and Religious Features of Medieval Arabic Medicine," in Asian Medical Systems: A Comparative Study, ed. Charles Leslie (Berkeley: University of California Press, 1976), 45-6. The anecdote comes from 'Abd al-Lațîf al-Baghdādī, Kitāb al-Ifāda wa'l-i'tibār (London: Allen and Unwin, 1965), 176 and 272-6.

316 al-Rāzī, Kitāb Shukūk 'alā Jālīnūs, 2. The English translation is slightly modified from a passage in M. Mohaghegh's afterward to the book. 
else he produced it as an old man whose great mind had become addled by exposure to arsenic and sulfur in the course of his alchemical studies. ${ }^{317}$ This reverential attitude toward Galen is significant not only for comprehending gynecology and embryology in medieval learned medicine, but also for understanding the ambivalence and the criticisms leveled by some jurists against the culture of Arabo-Galenic medicine. Such attitudes will be explored in chapter 6 .

\section{Greek antecedents to medieval gynecological concepts}

\section{Moisture, menstruation, and health in Hippocratic texts}

In their gynecological statements the Arabo-Galenic physicians explicitly drew on Hippocratic theory and practice, despite lacking direct access to some of the major Hippocratic gynecological texts. Hippocratic medical theory characterized women's health, and the difference between women and men, through the lens of polar opposites: dry and moist, right and left, hot and cold, etc. ${ }^{318}$ Hippocratic gynecology in particular associated women with moisture, while Aristotelian and Galenic gynecology placed emphasis on characterizing women as colder than men. These opposites recur throughout Arabo-Galenic gynecological writings, with masculinity associated with heat, ${ }^{319}$ dryness and the right side, and femininity associated with cold, moisture and the left side. ${ }^{320}$

The most obvious evidence of women's "moisture" was menstruation, but the characterization was not localized to the uterus, rather it defined women's entire physiology. According to Hippocratic gynecology, women are moist because their softer, porous flesh retains fluid more than does the less-porous flesh of men. ${ }^{321}$ Men rid themselves of what excess fluid they have through per-

317 Mohaghegh, Kitāb Shukūk 'alā Jālīnūs, 112.

318 On the internal consistency of the gynecological works and their relation to the rest of the Hippocratic corpus see, A. E. Hanson, "Continuity and Change: Three Case Studies in Hippocratic Gynecological Therapy and Theory,” in S. Pomeroy Women's History and Ancient History (Chapel Hill: University of North Carolina Press, 1991), 76-7.

319 There is some inconsistency in the Hippocratic texts with regard to heat. Diseases of Women I says that "a woman has hotter blood, and because of this she is hotter than a man," while in Regimen for Health it says "Females, inclining more to water, grow from foods, drinks and pursuits that are cold, moist and gentle. Males, inclining to fire, grow from foods and regimen that are dry and warm."

320 Weisser, Zeugung, Vererbung, und pränatale Entwicklung, 275.

321 Text in A. E. Hanson, “Hippocrates: Diseases of Women 1," Signs 1 (1975), 572. 
spiration. Women, however, must do so through menstruation, pregnancy (in which case menstrual blood nourishes the fetus) or lactation. ${ }^{322}$

Whereas biomedical gynecology understands menses as merely the shed lining of the uterus, the Hippocratics understood the menses as a large quantity of excess fluid which filled the uterus to capacity before being evacuated through menstrual bleeding. They estimated that a healthy woman discharges approximately one pint of blood each cycle, about seven or eight times as much as is estimated in studies of twentieth-century women. ${ }^{323}$ The process through which all this fluid was evacuated could easily be impeded, so they thought, leading to a build-up of "retained menses." If the "retained menses" were not evacuated, the uterus would become overfull, thereby causing pain and serious disease.

The entire extant fragment of the Hippocratic treatise Diseases of Young Girls is devoted to describing the dangers risked by women whose excess moisture is not given a proper outlet.

\begin{abstract}
Afterwards blood is gathered into their wombs for evacuation. Yet, when the mouth of the exit is not opened and more blood flows in due to their nourishment and the increase of their body, then the blood, not having a way to flow out, rushes from the quantity towards the heart and the diaphragm. When these parts are filled, the heart becomes numb; then lethargy seizes them after the numbness, then after the lethargy, madness seizes them . . .

When these things occur in this way, the young girl is mad from the intensity of the inflammation; she turns murderous from the putrefaction; she feels fears and terrors from the darkness. From the pressure around the heart, these young girls long for nooses. Their spirit, distraught and sorely troubled by the foulness of their blood, attracts bad things, but names something else even fearful things. They command the young girl to wander about, to cast herself into wells, and to hang herself, as if these actions were preferable and completely useful. Even when without visions, a certain pleasure exists, as a result of which she longs for death, as if something good ...

Release from this comes whenever there is no impediment for the flowing out of the blood. I urge, then, that whenever young girls suffer this kind of malady they should marry as quickly as possible. If they become pregnant, they become healthy. If not, either at the same moment as puberty, or a little later, she will be caught by this sickness, if not by another one. Among those women who have regular intercourse with a man, the barren suffer these things. ${ }^{324}$
\end{abstract}

322 Green, "The Transmission of ancient theories of female physiology," 16.

323 L. Dean-Jones, "Menstrual Bleeding according to the Hippocratics and Aristotle," Transactions of the American Philological Association 119 (1974), 181.

324 Ann Ellis Hanson and Rebecca Flemming "Hippocrates' 'Peri Partheniôn' (Diseases of Young Girls): Text and Translation,” Early Science and Medicine 3 (1998), 251-252. My emphasis. 
In this text, lack of regular menstruation is depicted not as menstrual absence but rather as menstrual retention, i.e. menstrual blood exists, but it is locked in and needs to be released or else it will overfill and damage the rest of the body. That release is best obtained through marriage and sexual intercourse. Sexual intercourse is itself credited with providing an outlet for menses. (There is some disagreement among classicists as to whether the Hippocratics thought of defloration as breaking a hymenal seal or stopper which then allows the menses to flow out, or whether sexual intercourse was thought to dilate the veins and the cervix, thereby providing a wider channel for the exiting menses. ${ }^{325}$ ) Thus irregular or absent menstruation is not understood as indicative of a girl being too young to have reached full physical maturity, or too young to be married, but rather lack of marriage is depicted as barring her from reaching full physical health, thereby causing disease. Moreover, an even better outlet for excess menses is pregnancy and lactation, since menses nourish the fetus, and excess blood is the raw ingredient that when "cooked" is transmuted into breastmilk. If pregnancy and birth are particularly salubrious then, by extension, those who are married but barren are particularly at risk of ill health.

The Hippocratic gynecological treatises are thus premised on the notion that women who have reached puberty are subject to diseases if they are not regularly menstruating, pregnant, or nursing. Not only are menstruating, pregnant, and nursing women considered to be healthy, but Hippocratic medicine claims that women who have given birth are subject to less pain while menstruating and less severe disease. ${ }^{326}$ Such an understanding assumes that sexual intercourse and childbirth are necessary for women in order to avoid illness. Conversely, virgins, non-fertile women, and unattached widows are depicted as physically at risk. In this system, barren women are in a disadvantageous position not simply because they cannot produce children, but because they are thought to be suffering from injurious disease, one which may even lead to derangement and a propensity toward violence.

325 L. Dean-Jones, L. Dean-Jones, Women's Bodies in Classical Greek Science (Clarendon Press: Oxford, 1994), 50.

326 Ibid., 19. Cf. Diseases of Women I, 572 and Diseases of Young Girls. The latter is in Ann Ellis Hanson and Rebecca Flemming “Hippocrates' 'Peri Partheniôn' (Diseases of Young Girls): Text and Translation,” Early Science and Medicine 3 (1998), 251. 


\section{Women's anatomy and the female contribution to the embryo}

Three anatomically erroneous but significant assumptions with respect to female anatomy were passed from the Hippocratics to Galen and onward into Arabic medical literature. The first of these was the assumption that in a healthy woman there is a direct passage between the mouth, uterus, and vagina. Furthermore, $5^{\text {th }}$-century B.C. Greek anatomical thought implied that the uterus has olfactory capabilities, and thus a medical practitioner can attract or repel the uterus upwards or downwards within the body by introducing attractive or repellant substances to it via the vagina or mouth. Later Greek and Arabo-Galenic physicians rejected entirely the idea that the uterus can sense odor or move in response to it, yet the application of the same sorts of odorous substances continued to play a significant role in antique and medieval gynecology. Furthermore, Hippocratic gynecology assumed that a woman's fertility depended on her having an unobstructed channel between vagina, uterus, and nose. A blocked passage was understood as indicative of ill-health and sterility. A variety of medieval diagnostic practices continued to be predicated upon the existence of this passage but, as we shall see, medieval writers develop this line of thought in new and divergent ways.

The second anatomical error was the idea that the human uterus is "bipartite" 327 i.e. that the uterus is composed of two symmetrical cavities, a left one and a right one (as is true in the case of some animals). ${ }^{328}$ This assumption was used to explain why male and female fetuses develop differently in utero. It continued to hold sway in Galenic and later Arabic medicine despite the fact that, through reports of dissections, and possibly from internal examinations, Galen himself was aware that the uterus did not have two cavities. ${ }^{329} \mathrm{Me}-$

327 Modern biomedicine treats the bicornuate uterus as a rare and serious medical condition. A somewhat more common condition is the "uterine septum" in which a partition bifurcates an otherwise normally-shaped uterus. This condition often causes miscarriage.

328 The anatomists of Alexandria, Egypt, who performed dissections, correctly described the shape of the uterus. However, this information was not integrated into later gynecological theory. Alexandria seems to be the only place in the ancient Greco-Roman world where we know that dissection was performed. It seems it was tolerated there from the third century B.C. until the second century A.D. Ludwig Edelstein, Ancient Medicine (Baltimore: Johns Hopkins Press, 1967), 256.

329 Galen, De Uteri Dissectione, chap. 3, translated in Charles Mayo Goss, "On the Anatomy of Uterus," The Anatomical Record 144 (1962), 77-83. 
dieval medicine referenced the left and rights "sides" of the uterus in discussions surrounding fertility and pregnancy tests, as well as fetal development. ${ }^{330}$

The third error lay in the belief that there was a passage connecting the uterus to the breasts. The explanatory value of this passage was that it meant that changes in the breasts could be used to monitor changes in the uterus, particularly during pregnancy. Drawing on Hippocrates' Aphorisms 5:37-38, al-Rāzī writes, "If she was pregnant and her breasts suddenly shrivel, then she has experienced a miscarriage. And if she was pregnant with twins and one of her breasts shrivels, she has miscarried the [fetus] which is on that side. The signs of conception, whether it is a male or a female: males are on the right side [of the uterus] and females are on the left side, and it is only rarely otherwise." 331 The connection between breasts and uterus also held out the possibility of treating uterine ailments by means of the more accessible body part, for example by applying cupping glasses under the breasts and drawing blood from there to prevent excessive blood loss during menstruation. ${ }^{332}$ The passage between the uterus and the breasts was also useful for explaining lactational amenorrhea - it stood to reason that nursing women might not menstruate because their "excess" blood, which would otherwise be evacuated by menstruation, had been transformed into breastmilk. Finally, the existence of the connection between the breasts and the uterus suggested a biological relationship between the babies wet-nursed by women and those birthed by them, a relationship that fit in well with Islamic concepts of milk-siblinghood, which created legal ties of close kinship between a wetnurse and the nursing child. ${ }^{333}$

Notably missing from the gynecological teachings of Hippocrates and Aristotle is an awareness of the existence of the ovaries. Although ovaries are large enough to be visible without modern technology, it is thought that their existence only became widely known in the Greco-Roman scientific world in the $3^{\text {rd }}$ century B.C. thanks to Herophilus, even though others in the Mediterranean world had long been using ovariotomy in animals (and sometimes in women)

330 For beliefs about the divided uterus see Weisser, Zeugung, Vererbung, und pränatale Entwicklung, 275.

331 al-Rāzī, al-Ḥāwī fì al-țibb vol. 3, bk. 9:75. This closely follows Aphorisms 5:37-38.

332 Ibn al-Jazzār al-Qayrawānī and Gerrit Bos, Ibn al-Jazzār on Sexual Diseases and Their Treatment: a critical edition, English translation and introduction of Book 6 of Zād al-musāfir wa-qūt alhạdị (London, Kegan Paul International, 1997), 149 (Arabic), 272 (English.) Cf.

333 Giladi, Infants, Parents and Wet Nurses: Medieval Islamic Views on Breastfeeding and their Social Implications, 119. 
as a means of sterilization. ${ }^{334}$ The physicians of late antiquity and the medieval world, by contrast, were very much aware of the existence of ovaries and surmised that they were the female equivalent of testicles. However human ova, the existence of which continued to be a matter of debate until the $18^{\text {th }}$ century since they are almost too small to see with the naked eye, are entirely missing from both ancient and medieval gynecology. The lack of a detectable equivalent to semen raised the question of whether women produce a gamete, "seed," as men do.

The Hippocratic gynecological treatises did not explicitly lay out a theory of reproduction. ${ }^{335}$ They were, however, clearly based on a two-seed understanding of conception. In Hippocratic texts, semen constitutes the male seed. Women also secrete seed into their womb, where it encounters semen. The "female seed" is also a fluid, just as semen is; and this fluid is secreted during sexual arousal, just as semen is. As Leslie Dean-Jones writes, this is not a substance which the physicians claimed to have directly observed. Rather, "the female seed was not necessarily a visible secretion as a man's was; it was postulated because of its explanatory value in a hypothesis, not because it had been empirically observed . . . the female seed is by nature emitted into the womb. It only appears outside the womb if the womb is open contrary to nature."336

Aristotle argued against the notion that women produce seed as men do. Instead, he posited that menstrual blood is itself the female contribution to the embryo. He compared the semen and the menses to a carpenter and a block of wood. The menses are a material to which the semen provides the form. When the semen acts on the menses, it thereby creates something new, an embryo, just as the carpenter acts upon the wood to create a bed. ${ }^{337}$ This is known as the one-seed theory of generation. Aristotle offered a number of arguments against the idea that women produce a gamete. He claimed that women lack the "vital heat" necessary to concoct seed, that pre-pubescent boys resemble women and since the former cannot bring about conception the latter cannot either, and that women could not possibly be secreting seed because they are already secreting something else, namely menses. Among the arguments that have greatest implications for the treatment of childless women was his claim that male seed is secreted only where there is sexual pleasure and arousal, yet women get pregnant even when sexual intercourse is unwanted. This was

334 A. Preus, “Galen's Criticism of Aristotle’s Conception Theory,” Journal of the History of Biology 10 (1977), 67.

335 Dean-Jones, Women's Bodies in Classical Greek Science, 154.

336 Dean-Jones, Women's Bodies, 156.

337 Aristotle, Generation of Animals, 1, 18-22. 
proof to him that whatever it is that women are contributing to the embryo, it is not seed, for they make that contribution with or without pleasure.

This assertion that women can conceive regardless of whether they are sexually aroused potentially had both quite negative and positive ramifications for the social treatment of women. Those physicians who, unlike Aristotle, subscribed to the two-seed theory of conception, encouraged men to become attuned to their wives' sexual desires so as to increase the likelihood of the woman secreting seed, resulting in conception. ${ }^{338}$ On the other hand, in accordance with the two-seed theory, when a woman did become pregnant, the fact that conception occurred was evidence that the woman was a willing participant in the sexual act. Authors such as Soranus and al-Rāzī claimed that conception is possible only when women ejaculate, ${ }^{339}$ thus indicating that impregnated women are willing sexual partners even in cases of purported rape. ${ }^{340}$ Their view also implied that a woman's sterility can be blamed on her sexual frigidity. By contrast, Aristotle's position de-incentivized paying attention to women's sexual desires, since they are unimportant from the perspective of reproduction. However, it also supported the notion that conception can occur without impugning the virtuous intent of a sexually assaulted woman. It also absolved infertile women of the charge that their reproductive failure is attributable to a lack of sexual ardor for their husbands. The great adherent of Aristotelian thought among the medieval physicians, the philosopher Ibn Rushd (Averroes), drew a connection between Aristotle's assertion and listening to women's claims. "Aristotle has argued that a woman can get pregnant without ever experiencing emission. I too have pursued this matter by observation and found it to be true . . . I have also asked women about it, and they tell me the same. That is, they often become pregnant without experiencing pleasure."341

Five hundred years after Aristotle, Galen drew upon the discovery of ovaries and on Aristotle's own work to criticize Aristotle's reproductive theories. Accord-

338 See al-Rāzī, al-Ḥāwī fī al-țibb, vol. 3, bk. 9:66. Ibn Sīnā, Qānūn fī țibb, 2:550 = Kitāb III: Fann 20: maqāla 1: fasl fì 'udhr al-țabīb fī mā yu'allim min al-taldhīdh. Al-Baladī, Tadbīr al-hạabālā', 10. Weisser, Zeugung, Vererbung, und pränatale Entwicklung, 152. Cf. Aetius of Amida, "Sterile and useless (inane) are those women who are forced to have coitus against their will. For love presides over (is essential for) conception; and women in love conceive very often." Aetius of Amida, The Gynaecology and Obstetrics of the VIth century, tr. James Ricci (Philadelphia: Blakiston, 1950), 36.

339 Rāzì, al-Ḥāwī, 9:58.

340 Soranus, Gynecology 36-7.

341 Muhammad ibn Ahmad ibn Rushd, Kulliyāt fī al-țibb (Morocco: Ma‘had al-Jinirāl Frankū, Lajnat al-Abhāth al-'Arabīya al-Isbānīya, 1939), 30. Translation from Musallam, Sex and Society in Islam, 64. 
ing to Galen, Aristotle was correct in claiming that women lack the quantities of vital heat found in men, but that inequality of heat accounts for why male and female reproductive organs are fundamentally similar (as ovaries and testes are) rather than categorically different. According to Galen, heat pushes the genitals of male fetuses outward, whereas relative cold keeps the genitals of female fetuses inside. What emerges from this theory is a conceptualization of female anatomy not as entirely different from male anatomy, but rather as the mirror of it. Galen writes:

\begin{abstract}
All the parts, then, that men have, women have too, the difference between them lying in only one thing, which must be kept in mind throughout the discussion, namely, that in women the parts are within [the body], whereas in men they are outside . . . Consider first whichever ones you please, turn outward the woman's, turn inward, so to speak and fold double the man's, and you will find them the same in both in every respect. Then think first, please, of the man's turned in and extending inward between the rectum and the bladder.

If this should happen, the scrotum would necessarily take the place of the uteri, with the testes lying outside, next to it on either side; the penis of the male would become the neck of the cavity that had been formed; and the skin at the end of the penis, now called the prepuce, would become the female pudendum [the vagina] itself. Think too, please, of the converse, the uterus turned outward and projecting. Would not the testes [the ovaries] then necessarily be inside it? Would it not contain them like a scrotum? Would not the neck [the cervix], hitherto concealed inside the perineum but now pendent, be made into the male member? And would not the female pudendum, being a skin-like growth upon this neck, be changed into the part called the prepuce? It is also clear that in consequence the position of the arteries, veins, and spermatic vessels [the ductus deferentes and Fallopian tubes] would be changed too. In fact, you could not find a single male part left over that had not simply changed its position; for the parts that are inside in woman are outside in $\operatorname{man}^{342}$
\end{abstract}

According to Galen, the heat possessed by men makes their bodies efficiently use up all of their nutrients through normal masculine activity. Due to women's diminished heat "the female is less perfect than the male ... for if among animals the warm one is the more active, a colder animal would be less perfect than a warmer." ${ }^{343}$ This imperfection creates an inefficiency that keeps women from using up all their nutrients and gives them an excess which can be used to nurture the fetus, whereas men in their efficiency cannot do so. In this model, the menses are both a raw material from which the fetus will be fashioned and the nutrient for the fetus, but they are not the female gamete. The female gamete

342 Galen, On the Usefulness of the Parts of the Body, 2:628-9.

343 Galen, On the Usefulness of the Parts of the Body, 2:628. 
is a seed like the male seed, but thinner and colder and therefore less impactful. It is produced in the female testes (ovaries) and transmitted from them to the uterus through tubes that are analogous to the seminal vesicle. Galen claims to have observed this female sperm. From his descriptions, it seems he is referring to a mucus discharge in the uterus. ${ }^{344}$ This Galenic concept of the male and female genitals as inside-out versions of each other is reiterated by the medieval physicians of the Islamic world, ${ }^{345}$ as are modified versions of his two-seed theory. ${ }^{346}$

\section{Infertility and its treatment in Greek medicine}

Both the Hippocratics and Aristotle recognized that a couple's lack of children may be due to infertility stemming from either partner, male or female, or both. ${ }^{347}$ However, in those authors' works, male infertility was not fully medicalized in the sense that the physician might want to look for it, diagnose it and suggest a course of action to correct it. As Rebecca Flemming writes:

[References in Aristotle to male infertility] are all essentially theoretical, about causes not cures (though GA 747a3-22 provides diagnostic advice); and the first does not even refer to specific explanations for male infertility. Similarly, the few explicit Hippocratic engagements with male reproductive failure (the Scythians in Airs Waters Places $21,{ }^{348}$ and the

344 M. Boylan, “Galen's Conception Theory,” Journal of the History of Biology 19 (1986), 62. 345 Cf. Ibn Sīnā, Qānūn fì al-ṭibb, 2:555-6 = kitāb III: fann 21: maqāla 1: faṣl fī tashrīh al-rahim. Ibn Zuhr, Kitāb al-taysīr (Rabat: Akādīmiyyat al-Mamlaka al-Maghribiyya, 1991), 340. al-Majūsī, Kāmil al-șinā'a fĩ al-țibb (Cairo: al-Maṭba'ah al-Kubrā al-'Āmira, 1877), 1:123. 'Alī ibn Sahl Rabbān al-Ṭabarī, Firdaws al-ḥikma, 34.

346 B. Musallam, "The Human Embryo in Arabic Scientific and Religious Thought," in The Human Embryo: Aristotle and the Arabic and European Traditions, ed. G. R. Dunstan (Exeter: University of Exeter Press, 1990), 33-4.

347 R. Flemming, "The Invention of Infertility in the Classical Greek World: Medicine, Divinity, and Gender," Bulletin of the History of Medicine 87 (2013), 571.

348 The Scythians are said to have sterilized men by cutting a nerve behind the ear and thereby disrupting the production of semen, which was thought to occur initially in the spinal column. Interestingly, this notion made its way not only into the medical commentary tradition, but also in the hisba tradition. In his manual for market inspectors, the $6 / 12^{\text {th }}$-century muhtasib al-Shayzarī, who practiced somewhere in the Syria / Palestine / Egypt region, writes that one should not permit phlebotomists to bleed the veins behind the ears because that causes sterility. He says there is a debate regarding whether cutting into the vein behind one ear only has a sterilizing effect. Kitāb nihāyat al-rutba fi țalab al-ḥisba lil-Shayzarī (Cairo: Lajnat al-ta'lif wa'l-tarjama wa'l-nashr, 1946), 92. 
enigmatic Aphorisms 5:63 $3^{349}$ ) are never followed up therapeutically. All these authors are, of course, deeply committed to the importance of the male contribution to generation; but its dysfunction seems not to be medicalized..$^{350}$

While these texts acknowledge the reality of male infertility, they have little to say about how to diagnose it and provide no information about how to remedy it. In part, this can be attributed to the perception that the easiest way to deal with a man's seeming lack of fertility is to have him attempt to reproduce with another woman. In Generation of Animals, Aristotle writes that one can test whether a man's semen is fertile by placing it in a vessel with water and seeing if it sinks to the bottom (in which case it is) or floats to the surface (in which case it is not). ${ }^{351}$ However, he also writes, "in knowing the causes [of sterility] on the husband's side there are various signs to be taken, but taking those that are mostly easier, let him be observed to have intercourse with other women and to generate." ${ }^{352}$ Although this attitude is later echoed in the Qānūn of Ibn Sinnā (d. 427/1037) as well as in al-Majūsī’s (d. 384/994) Kāmil al-șinā'a al-țibbiyya with some modifications, medieval Arabic texts devote somewhat more attention to male infertility than did Greek ones. ${ }^{353}$

By contrast, female fertility and infertility is the subject of a great deal of medical diagnostic, prognostic, and therapeutic interest in ancient medicine. Remarkably, of the 1500 pharmacological recipes found in the Hippocratic corpus, $80 \%$ are gynecological and found in treatises devoted to women's fertility. ${ }^{354}$ The

349 The aphorism is "[V:62] Women who have the uterus cold and dense (compact?) do not conceive; and those also who have the uterus humid, do not conceive, for the semen is extinguished, and in women whose uterus is very dry, and very hot, the semen is lost from the want of food; but women whose uterus is in an intermediate state between these temperaments prove fertile. [V:63] And in like manner with respect to males; for either, owing to the laxity of the body, the pneuma is dissipated outwardly, so as not to propel the semen, or, owing to its density, the fluid (semen?) does not pass outwardly; or, owing to coldness, it is not heated so as to collect in its proper place (seminal vessels?), or, owing to its heat, the very same thing happens.” Translation by Francis Adams.

350 R. Flemming, "The Invention of Infertility in the Classical Greek World: Medicine, Divinity, and Gender," n. 23.

351 Aristotle, Generation of Animals II 7:747a, 3-7. Cf. Ibn Sīnā, al-Hayawān XVI = volume 8 of al-Shifä' (Cairo: al-Hay’a al-Mișrīya al-'Āmma lil-Ta'līf, 1970), 2 :409 Cf. Weisser, Zeugung, Vererbung, und pränatale Entwicklung, 152.

352 Aristotle, History of Animals Vol VII-X, Tr. D. M. Balme (Cambridge: Loeb Series, Harvard University Press, 1991), 636b11.

353 al-Majūsī, Kāmil al-șinā'a fì al-țibb, 2:467.

354 L. Totelin, Hippocratic Recipes: Oral and Written Transmission of Pharmacological Knowledge in Fifth- and Fourth-century Greece (Boston: Brill, 2008), 2, 197. 
Hippocratic treatises also include dozens of tests to diagnose fertility or lack thereof. These texts describe many causes of female infertility, which may be categorized as follows:

(1) The inability of semen to pass into the uterus due to a narrowness or blockage in the passage between the vagina and the cervix, or due to the abnormal shape or position of the uterus. The blockage may be attributed to the retention of "old" menses which have coagulated, having failed to be fully evacuated.

(2) The inability of the uterus to retain the male semen, and the subsequent "slipping out" of the semen due to either the failure of the uterus to "close" over the cervix or to an unhealthy smoothness and slipperiness in the uterus. This slipperiness may be caused by an excess of moisture, coagulated blood, or ulcers.

(3) An excess or deficiency of heat or moisture in the uterus which "overcooks" or "dries out" the seed.

(4) Dyskrasia, i.e. an overall humoral imbalance in the woman's body. ${ }^{355}$

Despite having a very different understanding of how reproduction occurs, both Aristotle's and Galen's descriptions of the potential causes of female infertility are quite similar to the Hippocratic ones, and Aristotle seems to draw heavily upon the Hippocratic treatise On Barrenness. ${ }^{356}$ Aristotle describes the problem of the smooth, slippery uterus, deficient moisture in the uterus, and general humoral imbalance. ${ }^{357}$ Galen explains that menstrual blood helps provide the uterus with texture, and lack thereof causes the uterus to be too slippery to retain the semen. ${ }^{358}$ These all enter into the medieval medical literature as well.

On Barrenness also mentions diagnostic measures for establishing infertility based on physical touch. "If the mouth of a woman's uterus or its neck becomes hard, this will be recognized when she palpates with a finger, and also if her uterus is turned aside toward her hip. When the case is such, do not give any sharp suppository - for if the mouth of the uterus ulcerates after becoming inflamed, there is a great danger that barrenness will result." ${ }^{359}$ Note that, in this phrasing,

355 Hippocrates, Diseases of Women I, §11, Cf. Galen, On Hippocrates' On the Nature of Man, $\S 47-49$.

356 A. Preus, "Biomedical Techniques for Influencing Human Reproduction in the Fourth Century B.C.," Arethusa 8 (1975), 246.

357 Aristotle, History of Animals VII.2-3 (582-3). Cf. Galen, On Hippocrates' On the Nature of Man, §48.

358 Galen, On the Anatomy of the Uterus, 81 (chapter 10).

359 Hippocrates, On Barrenness § 230. Translation by Paul Potter. Hippocrates Vol. X, 367. 
it appears that the female patient herself conducts the intimate examination to find out whether the cervix is hard. While it seems that this information is meant to be communicated to the medical practitioner, it is not the practitioner himself who conducts the manual examination. Similarly, in On Barrenness the medical practitioner is instructed to prepare sitz-baths and pessaries for the patient, to lay out blankets for her, and to make sure she does not burn herself, but it is the patient herself who inserts the pessary. ${ }^{360}$

On Barrenness mentions several categories of treatments for those diagnosed with infertility: eating certain foods the utility of which is not always explained, clearing the passage between vagina and mouth by means of sitz-baths, pessaries, and fumigations, or introducing probes to change the width of the vagina; or changing the texture or environmental qualities of the uterus by inserting "fertilizing" substances or using probes. Some of the ingredients in Hippocratic fertility recipes are known to have been attached to specific qualities, for example boiled foods were thought to make the body more soft and moist, red wine to make it dryer and harder, etc. Other ingredients were associated with purgation and excretion: puppy and octopus meat, for example, were believed to have a laxative effect. ${ }^{361}$ In On Barrenness, both eating boiled puppies and fumigating with them are recommended for removing blockages in the passage to the uterus. ${ }^{362}$ Other fertility ingredients are those found in perfumes, which were themselves closely associated with sexual stimulation and intercourse in Greek antiquity. ${ }^{363}$ These include frankincense, myrrh, cinnamon, cassia and styrax, ${ }^{364}$ all of which also play a prominent role in the medieval period. Castoreum (a substance extracted from the glands of beaver foreskins) had a similar use and was associated almost exclusively with "women's medicine." 365 Known in Persian and

360 Ibid., § 221.

361 Hippocratic Recipes, 198.

362 Hippocrates, On Barrenness §218 and 230.

363 Totelin explains "Perfumes played an important role in sexual preliminaries in ancient

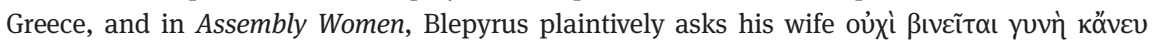
uv́pov; (Can’t a woman fuck without perfume?). Perfumes appear frequently in the Hippocratic gynaecological recipes ... [many] pessaries in the Hippocratic collections of recipes, [had] to be dipped in perfume before being applied. This act of dipping a pessary in scented oil may be the equivalent of anointing the genitalia and other parts of the body before sexual intercourse; it serves as a preliminary to penetration. The perfume that is most commonly used in the Hippocratic recipes to facilitate the insertion of a pessary is rose oil. This again might not be a coin-

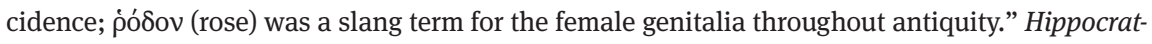
ic Recipes, 204.

364 Totelin, Hippocratic Recipes, 150

365 Ibid., 161. 
Arabic literature as jundbādastar, castoreum continued to be particularly associated with the treatment of uterine problems from ancient Greek antiquity through the modern period. (It continued to be used in the West until the early $20^{\text {th }}$ century to treat spasms and hysteria and to induce labor after intrauterine fetal death. ${ }^{366}$ ) Others ingredients are associated with fertility due to their having shapes or names reminiscent of sexual organs, such as stag horns, figs, radishes, myrtle, squirting cucumber, and gourds. We know how they were viewed because many of the Hippocratic ingredients also appear in ancient plays where it is clear they have sexual connotations. Not all of these ingredients continued to have sexual association in later periods. This is true of celery, for example, which in the ancient Greek comedies represents female sexual organs, or barley and pennyroyal which connoted pubic hair. (Of all these ingredients, only pennyroyal is currently known to have chemical effects of pharmacological value. The essential oil of pennyroyal is lethally toxic and was used as an emmenagogue and abortifacient until the early $20^{\text {th }}$ century. It also has muscular and hallucinogenic effects.) Other ingredients were believed to open the uterus and expel what it retained, whether menstrual blood which needed to be purged or a dead fetus which needed to be forced out. The drugs associated with this purgation included pennyroyal, silphium, squirting cucumber, and gourds. ${ }^{367}$ In medieval texts, the squirting cucumber in particular became associated with these functions. ${ }^{368}$ It is also known as wild cucumber, or ecballium elaterium, or in Arabic as qiththā' al-himār, qiththā' barrī or 'alqām. ${ }^{369}$ Of course, in the Arabic texts, the repertoire of materia medica is significantly expanded.

366 Michael J. O’Dowd, The History of Medications for Women: materia medica woman (New York: Parthenon Pub. Group, 2001), 88-89.

367 Totelin, Hippocratic Recipes, 214-19.

368 It appears, for example in Ibn al-Jazzār al-Qayrawānī’s Ṭibb al-fuqarā’ as an abortifacient in his chapter "On Treatment of Diseases of the Uterus, Menstrual Retention, and Bringing Down the Fetus," and in his Zād al-musāfir in three places (emmenagogue, abortifacient, and ingredient in a treatment for gout). Ibn al-Jazzār al-Qayrawānī, Tỉbb al-fuqarā’ wa'l-masākīn (Tehran: Mu'assasah-’i Muṭāla‘āt-i Islāmī, Dānishgāh-i Tihrān, 1996), 158. Ibn al-Jazzār al-Qayrawānī and G. Bos, Ibn al-Jazzār on Sexual Diseases and Their Treatment: a critical edition, English translation and introduction of Book 6 of Zād al-musāfir wa-qūt al-ḥādir (London, Kegan Paul International, 1997), 141, 195, 235.

369 See Dioscorides and T.A. Osbaldeston, Dioscorides De Materia Medica: a New English Translation (Johannesburg: IBIDIS, 2000), 707 (Bk 4:155). Ibn al-Jazzār, Ibn al-Jazzār on Sexual Diseases and Their Treatment, 291. According to John Riddle, modern medical testing has confirmed the contraceptive but not the abortive qualities of the squirting cucumber. J. Riddle, Contraception and Abortion from the Ancient World to the Renaissance (Cambridge: Harvard University Press, 1992), 54. 
Lack of menstruation is also acknowledged in ancient and medieval texts as either an underlying cause or a sign of infertility. These texts often depict amenorrhea as a form of constipation, rather than menstrual absence. The woman produces menses, but the blood is retained by the uterus rather than evacuated from it, which results in infertility because the male semen is either physically blocked from reaching the uterus, or because the retained menses have congealed or rotted resulting in a toxic uterine environment. The first step, therefore, to promoting fertility is to supply an emmenagogue to "bring down" the retained menstrual blood from the uterus. A large number of the gynecological recipes, both ones associated with fertility and ones thought to be contraceptives, are described as promoting this menstrual "regularity." In the medieval period, the association of bleeding (in the form of menses) with the return of fecundity to barren women is so strong that virtually all medieval commentaries on the Qur'ān, and likewise Tales of the Prophets, describe the restoration of fertility to the barren wives of Abraham and Zechariah in terms of the sudden onset of menstruation. ${ }^{370}$

Importantly, whereas today a "missed period" is the classic first indication of pregnancy, the Greek physicians (and, it seems, later physicians as well) did not seem to view disrupted menstruation in quite the same manner, even though they were well aware that amenorrhea is a symptom of pregnancy. ${ }^{371}$ This means that when a non-menstruating woman was given an emmenagogue or underwent a surgical procedure to trigger a menstrual cycle in the hopes of her getting pregnant, it is possible that the resulting blood was in fact an abortion.

One method of treating infertility was the insertion of wood, lead, or tin probes through the vagina and into the uterus. ${ }^{372}$ Hippocrates suggests this form of treatment to cure amenorrhea and initiate a menstrual cycle and thus a fertility cycle, to widen the vagina or dislodge a blockage in the uterus, or to change the texture of the uterus and make it less smooth and thereby enable it to retain semen more easily. We have encountered the use of such a probe in chapter 1 , in the case of Magdalena from $17^{\text {th }}$-century Catholic Spain. If con-

370 E.g., Ibn Kathīr, Qișaș al-anbiyā', glosses Q. 21:90, which refers to God fixing Zakariyyā's wife for him, and explains that it means that previously she did not menstruate and then God made her do so. Cf. al-Shaybānī and Ibn Kathïr's Tafsīr on Q. 21:90 and Ibn al-Jawzī’s Ibn al-Jawzì's Zād al-masìr fī 'ilm al-tafsīr on Q. 11:70.

371 H. King, Hippocrates' Woman: Reading the Female Body in Ancient Greece, 32 and Rebecca Flemming, Medicine and the Making of Roman Women: Gender, Nature, and Authority from Celsus to Galen (New York: Oxford University Press, 2000), 162. Cf. Hippocrates’ On Barrenness §215. Although see Aphorisms IV:61.

372 Hippocrates, Superfetation, § 29; On Barrenness, §217, 221, 228, 238, 244. 
ducted early in a pregnancy, before the existence of the pregnancy was evident to the woman, such probing would certainly have caused an abortion, which would have looked like the onset of menstruation. ${ }^{373}$ The probe could also cause further damage to the internal organs, thereby creating even more impediments to fertility. In Arabo-Galenic medicine, probes or hooks (șināra) appear in the context of treating ratq, the condition in which the vagina is too narrow or is blocked by excess tissue.

Throughout Greek medical literature, and subsequently, there are substances and even surgical techniques that are mentioned both as abortifacients and as means for promoting fertility. It could be argued that this is simply due to the fact that many substances, such as wine, honey or frankincense, had multiple medical uses or were thought to be panaceas. However, certain substances such as wormwood, pennyroyal, and fenugreek were not simply general panaceas but rather seem to have maintained millennia-long reputations as "women's drugs." From a biomedical point of view, the conflation of abortifacients with fertility agents has a peculiar logic. Both first-trimester miscarriages and the beginning of the reproductive cycle (in the form of menstruation) are characterized by vaginal bleeding. Moreover, amenorrhea may be either a symptom of pregnancy or a symptom of hormonal disruption associated with infertility. ${ }^{374}$ Therefore, a treatment which resulted in vaginal bleeding may have induced either menstruation, or hemorrhage, or fetal death or uterine contractions so as to cause an abortion. Moreover, because the fetus is so small in the early stages of pregnancy, the different phenomena would have been difficult to distinguish. Therefore, it seems likely that sometimes when women thought they were taking substances to begin a menstrual period so as to promote fertility, in fact they were prematurely ending an undiagnosed pregnancy. There were, of course diagnostic tools for determining whether a woman is already pregnant. For example, On Barrenness offers the following test: "Grind red ocher and anise very fine, dissolve in water, give (sc. to drink), and let the woman sleep. If colic comes on around her navel, she is pregnant: if this does not happen, she is not." ${ }^{375}$ The same test, but with hydromel instead of ocher, is proposed in Hippocrates'

373 A. Preus, "Biomedical Techniques for Influencing Human Reproduction in the Fourth Century B.C.," 249.

374 Etienne van de Walle et al., Regulating Menstruation: Beliefs, Practices, Interpretations (Chicago, University of Chicago Press, 2001). This book explores the notion that discussion of the medical goal of "regulating" menstruation, in many cultures and periods throughout the world, has served as a device for communicating information about abortifacients.

375 Hippocrates, On Barrenness, §215. Translation by Paul Potter. Hippocrates Vol. X, (Cambridge, MA: Harvard University Press, 2012), 341. 
Aphorisms 5:41. This diagnostic tool also appears frequently in medieval manuals, together with explanations as to why the test is effective (these explanations are not present in the Hippocratic treatise). ${ }^{376}$

Throughout antiquity and into the medieval period, the treatment of infertility related in some respects to the medical theories surrounding conception and female anatomy but did not altogether accord with them, since treatments were premised on ideas that stood apart from the theory. For example, diagnostic interest in menstrual blood and therapeutics intended to alter the qualities of menstrual blood remained a constant of medieval treatments of infertility, even though the significance of menstruation to the reproductive process was a matter of intense dispute and subject to diverse medical opinions. The importance of introducing pleasant smells into the uterus, for the sake of improving or maintaining reproductive health, remained constant, even after the medical community had come to the consensus that the uterus cannot move and does not have the olfactory capability to be attracted or repelled by odors. The disjuncture between conception theory and therapeutic practice can also be seen in attitudes toward male infertility, for though it was theoretically acknowledged that men could be the source of infertility, it was never fully embraced therapeutically. Moreover, therapeutic techniques were not limited to or grounded in conception theory. We see this, for example, in the emphasis on the use of sexually suggestive ingredients to promote reproductive health. All of this indicates that while treatment techniques could find justification in prevailing scientific theory, they were not dependent upon it.

376 E.g. 'Alī ibn Sahl Rabbān al-Ṭabarī, Firdaws al-ḥikma fī al-țibb, 38 and al-Rāzī, al-Ḥāwì fĩ $a l-t i b b$ vol. 3, bk. 9:51. In a fascinating Latin account, De Secretis Mulierum of Psudeo-Albertus Magnus (late thirteenth-century), the author describes this test as being surreptitiously administered, as a means of uncovering the truth when a woman would otherwise wish to the conceal whether or not she is pregnant. He warns that "some women, however, are so clever and so aware of the trick that they refuse to tell the truth." H.R. Lemay, Women's Secrets: A Translation of Pseudo-Albertus Magnus's “De Secretis Mulierum” with Commentaries (Albany: State University of New York Press, 1992), 125. 


\title{
Etiology and treatment of female infertility in Arabo-Galenic medicine
}

\section{Infertility in the Firdaws al-hikma (Paradise of Wisdom)}

What follows is an analysis of the discussion of infertility found in the Firdaws al-hikma (Paradise of Wisdom), written around the year 236/850 by the physician 'Alī ibn Sahl Rabbān al-Ṭabarī, a Syriac Christian convert to Islam who lived in Persia and Iraq. The relevant sections of the Firdaws al-hikma have the advantage of being both comparatively succinct and representative of the sorts of discussions of infertility found in many subsequent Arabo-Galenic medical works. Al-Tabari begins his discussion of diseases of the uterus with the following list of gynecological concerns.

\begin{abstract}
Among the greatest of maladies afflicting the uterus are infertility, the slipping out of the seed, the miscarriage of the fetus, uterine suffocation, hemorrhage of menstrual blood, retention of menstrual blood, tumors, and dyscrasia. ${ }^{377}$ For if there is an excess of heat the seed is burned. An excess of cold freezes it. If there is an excess of moisture, or the ability to hold on ${ }^{378}$ to the seed is weakened, the seed slips out. If there is an excess of dryness it desiccates and dries up the seed. ${ }^{379}$
\end{abstract}

Al-Tabarī's list begins with infertility, and then proceeds to enumerate a variety of concerns ending with dyscrasia which, as he explains, leads to the "seed" either the gametes or embryo - failing to thrive. In this list al-Ṭabarī seems to categorize infertility as both an illness in and of itself, and as a symptom and consequence of other conditions. He does not fully differentiate between causal factors for infertility, etiological types of infertility, and comorbidities associated with infertility. These topics are all discussed together.

Al-Tabari begins by explaining the danger an adverse environment poses to the "seed." Like a literal plant-seed, the human seed can only thrive in environments with appropriate levels of warmth and moisture. Al-Tabarī does not specify whether "seed" refers to the embryo itself or to the male or female gametes

377 Cf. al-Majūsī, al-Kāmil, 1:388 and Weisser, Zeugung, Vererbung, und pränatale Entwicklung, 158.

378 misāk $a$ = holding in, retention. I have avoided translating the word as retention only because in this particular context it would be confused with ihtibās al-dam, retention of the (menstrual) blood. Misāka was also the word used in the legal texts to refer to urinary and fecal continence.

379 al-Ṭabarī, Firdaws al-ḥikma fī al-țibb, 273. Cf. Ibn Sīnā, Qānūn fì al-ṭibb, 2:562 = kitāb III: fann 21: maqāala 1: faṣl fì dalā’il al-bard fì al-raḥim. 
prior to conception. Indeed, his guidance is not constructed upon a particular understanding of what constitutes the female contribution to the embryo or of the stages of embryonic development. Rather, his guidance is based both on humoral notions of achieving balance, and on analogical inferences about what conditions cause plant seeds to thrive or die.

The emphasis on the harmful effects of excessive heat, cold, moisture, and dryness is found in virtually all subsequent discussions of the pathologies of the uterus in Arabo-Galenic medicine. Such conditions are largely depicted as curable, through fumigations and foodstuffs meant to restore the correct balance of heat and moisture. ${ }^{380}$ Sometimes these foodstuffs are described as directly impacting heat, and there are "warming" foods or "cooling" ones. At other times the treatments are meant to aid in the production of one of the four humors: blood (characterized by heat and moisture), phlegm (cold and moisture), yellow bile (heat and dryness), or black bile (cold and dryness).

Excessive heat and cold in the uterus, in addition to creating an inhospitable environment for the seed, are also depicted as potential impediments to conception because they affect the quantity and viscosity of menstrual blood. Menstrual blood that is too thin or thick does not flow out properly, and thus becomes stuck in the uterus or clogs blood vessels. ${ }^{381}$ This old blood can impede pregnancy by coagulating into a barrier near the cervix, thereby preventing semen from reaching the uterus, or by coating the wall of the uterus thereby making it too slippery to retain the embryo, or by rotting and producing noxious fumes which poison the uterine environment. Infertility due to this menstrual retention is treated by ingesting drugs, applying pessaries, and using fumigation techniques, the purposes of which are to make the blood flow out more easily and evacuate from the womb.

Al-Tabari explains that excessive moisture and other conditions can also cause infertility by making the uterus too smooth for the seed to adhere within the womb. He writes, "Among the things that prevent conception are conditions in the uterus itself, such as ulcers, stiffness, excessive coarseness, or viscous phlegm. These make it slippery such that it cannot retain the seed in it." 382 The concern that conditions within the uterus could make it physically unable to keep either semen or the embryo from slipping out is found throughout both Greek and Arabic texts. When this slipperiness is attributed to excessive moisture, it can be corrected by having the woman take measures to bring

380 al-Ṭabarī, Firdaws al-hikma, 40.

381 Cf. Ibn al-Jazzār, Ibn al-Jazzār on Sexual Diseases and Their Treatment, 263.

382 al-Ṭabarī, Firdaws al-hikma, 274. 
about "dryness." 383 Such measures include ingested pills and decoctions, compresses, enemas, pessaries, and fumigations meant to absorb or draw out excess moisture. The recipes for these pessaries and fumigations, particularly as described by Ibn Sīnā, often combine one or two dozen ingredients. ${ }^{384}$ Slipperiness can also be attributed to an unreceptive texture in the uterine wall, a result of the scarring over of previously healed ulcers and abscesses. While ulcers, tumors, and wounds to the uterine wall are considered to be treatable by medieval authors, the infertility that may result from them is usually not. ${ }^{385}$

Al-Tabari continues his description of things that cause infertility by listing conditions that block the semen's path to the uterus.

Also, blood or a fleshy growth which blocks the path [to the uterus], the uterus disappearing from its place, ${ }^{386}$ or excessive fat in the part of the diaphragm nearest to the intestines. $^{387}$

These conditions are treated by diet, to promote fat loss, as well as surgery to remove growths in the vaginal canal. ${ }^{388}$

Al-Tabarī's discussion of infertility also addresses the problem of miscarriage. In some respects, the failure to conceive and the failure to sustain a pregnancy are not entirely differentiated, especially when conception failure is attributed to the uterus failing to retain seed. Conflation between miscarriage and this kind source of infertility is typical of some other medieval discussions as well, particularly in the Qānūn. ${ }^{389}$ Kueny characterizes these discussions as physicians' "near-obsessive interest in concocting ways to prevent miscarriage" based on their belief in women's carelessness and inadequacy. This interpretation is a mistake. The physicians do not pathologize healthy pregnancies so much as they elide over the distinction between a woman failing to conceive because the semen or embryo slips out of her uterus rather than embedding in it, and a woman failing to carry to term when the fetus detaches from the uterus and "falls out." In discussing the prevention of miscarriage, the authors are providing therapeutic advice to treat what is, in their view, a variant form of infertility.

383 Al-Baladī, Tadbīr al-ḥabālā', 28-29.

384 E. g. Ibn Sīnā, Qānūn fī al-țibb, 2:577-8 = kitāb III: fann 21: maqāla 2: faṣl fī ḥuqna jayyida 385 Ibn Sīnā, Qānūn fì al-țibb, 2:565 = kitāb III: fann 21: maqāla 1: al-tadbīr wa'l-'ilāj

386 I.e. uterine prolapse. Cf. Ibn al-Jazzār, Ibn al-Jazzār on Sexual Diseases and Their Treatment, 177.

387 al-Ṭabarī, Firdaws al-hikma, 274.

388 al-Zahrāwī, Albucasis on Surgery and Instruments, 457.

389 Cf. Ibn Sīnā, Qānūn fì al-țibb, 2:577 = kitāb III: fann 21: maqāla 2: faṣl fī hafẓ al-janīn 
Al-Tabari views miscarriage primarily as the dislodging of the embryo from the uterus. Childlessness which is a result of miscarriage or the inability to retain the embryo is treated by shielding the pregnant woman from physical or psychological experiences or malevolent forces which can cause her to move in a way which might jolt the embryo. At various times in the pregnancy, the connection between the embryo and the uterus is seen as particularly fragile.

Miscarriage can also result from excessive cold or indigestion, or grief, or a coarse wind, or an excess of phlegm in the veins of the uterus, or from a jump from a height to the ground, or a blow, or a strong jolt. ${ }^{390}$

Elsewhere in the Firdaws al-ḥikma, al-Ṭabarī explains:

[Miscarriage may result from] diarrhea, or a blow to her breast, or from a severe shock or fright, or because she hears an alarming noise, or due to exhaustion or severe misfortune or because she approaches things which by their natures abort the fetus. Among stones and the like there are those which protect the fetus and those which eject it from the womb, whether it is alive or dead. You will find this in its own chapter ... Hippocrates says, "Pregnant women, if they need treatment should receive treatment in the fourth through seventh month, but not before or after that." The reason for his statement is that during the first month the fetus is akin to a weak fruit which can be dislodged by a slight wind or movement, but in the eighth month it is akin to ripe fruit which is not dislodged by a slight wind or movement. ${ }^{391}$

Here, al-Tabarī lists a variety of direct and indirect causes of miscarriage. ${ }^{392}$ Drawing on an image and timeline found in Hippocrates, he notes that, in the early stages of pregnancy, the fetus is attached like an "unripe fruit" which can thus be easily dislodged. Listed among the misfortunes which can cause a miscarriage are body blows and emotional blows. It is not entirely clear from these passages whether the emotional blows are dangerous because psychological distress itself triggers the miscarriage, or whether the physiological assumption is that, when enduring psychological distress, the internal organs physically move or shudder, and it is this movement which physically dislodges the embryo. Note that here diarrhea is thought to be able to cause a miscarriage, and

390 al-Ṭabarī, Firdaws al-hikma, 274.

391 al-Ṭabarī, Fìrdaws al-ḥikma fĩ al-țibb, 39-40. Cf. Ḥunayn ibn Isḥāq, Kitāb al-mawlūdīn (Baghdad: Majma' al-Lugha al-Siryāniyya, 1978), 38. Ibn al-Jazzār, Ibn al-Jazzār on Sexual Diseases and Their Treatment, 285-6 and al-Rāzī, al-Ḥāwī fì al-țibb, vol. 3, bk 9:49-50 and al-Baladī, Tadbìr al-ḥabālä', 15-16.

392 Cf. Soranus, Soranus's Gynecology 45-46, which has a very similar list. 
it is not uncommon for bowel movements to be associated with anguish or strong emotional responses. ${ }^{393}$

In the middle of this passage about the physical and psychological triggers of miscarriage, al-Tabarī includes a description of stones and plants which, without being ingested, can also trigger miscarriage or protect women from miscarrying.

The head of the hospital of Jundīshāpūr informed me that there is, among a family in the village of Ahwaz, ${ }^{394}$ a stone which protects the fetus if it is tied to the pregnant woman. Moreover, we have heard that, according to the son of a revered Christian woman in Rayy, if this pregnant woman with this stone inadvertently encounters another pregnant woman, the one who does not have the stone with her will miscarry. Daylamite women inform me that this protective stone is widely available in Jīlān. Dioscorides mentions a plant called the fawflāfīqūs (=qawqlāqimūs? =cyclamen?), which resembles the bindweed leaf. According to his information, it is a thorn which is placed on wounds . . . if this leaf is affixed to a woman who is not pregnant, she then conceives. But, if a pregnant woman glances at it, then she miscarries. Pregnant women must be careful during the eighth month because if they miscarry there is a risk they will die, and should therefore avoid acute exhaustion, poor food, excessive washing, and sneezing. ${ }^{395}$

In his description of these stones and plants that can exert power on women's bodies without being ingested, al-Tabarī cites as authorities female informants and male intermediaries for female informants. He mentions a physician at the famous hospital of Jundīshāpūr, who himself refers to the folk knowledge of people in the surrounding villages. He also cites the son of an unknown Christian woman, and then refers to some Daylamite women with whom he appears to have had direct contact. Each of these informants refers to a stone or plant that affects women who encounter it. The stone serves as a sort of shield, not only protecting pregnant women from miscarriage and deflecting the threat posed by other pregnant women, but making the threat rebound upon the woman lacking the stone.

393 Cf. Ibid., 38: "For the seed is evacuated through fright, sorrow, sudden joy and, generally, by severe mental upset; through vigorous exercise, forced detention of the breath, coughing, sneezing, blows, and falls, especially those on the hips; by lifting heavy weights, leaping, sitting on hard sedan chairs, by the administration of drugs, by the application of pungent substances and sternutatives; through want, indigestion, drunkenness, vomiting, diarrhea; by a flow of blood from the nose, from hemorrhoids or other places; through relaxation due to some heating agent, through marked fevers, rigors, cramps and, in general, everything inducing a forcible movement by which miscarriage may be produced."

394 I.e., near the hospital in Jundīshāpūr.

395 Al-Ṭabarī, Firdaws al-ḥikma fì al-țibb, 39-40. 
As Manfred Ullmann notes, interest in the healing properties of stones, magical cures, and "sympathetic" cures is not divorced from "rational" medicine in Arabo-Galenic writings, but is it more prevalent in gynecology than in other areas of medicine. ${ }^{396}$ It is not surprising, therefore, that the one magic square depicted in the entire Firdaws al-hikma is to be found in the section on childbirth. ${ }^{397}$ (This is an early Arabic example of the ancient $3 \times 3$ buduh square, with the numerals in the rows and columns adding up to 15, and the numbers 2, 4, 6, and 8 at the corners. ${ }^{398}$ ) Ibn Sīnā too mentions many non-rational remedies for gynecological problems. ${ }^{399}$

Treatments involving the ingestion of the reproductive powers of animals are particularly common in the medieval (as well as ancient) gynecological literature. For example, Ibn Sīnā suggests that a woman experiencing infertility drink elephant urine at the time of coitus. ${ }^{400}$ The $7^{\text {th }} / 13^{\text {th }}$-century Egyptian guide to pharmacy, Minhāj al-dukkān, describes using an enema made of rabbit rennet for hastening conception, ${ }^{401}$ an ingredient which does not appear in other recipes in the book, but which is also recommended for fertility purposes in Dioscorides' Materia Medica. ${ }^{402}$ Similarly, a $5^{\text {th }} / 11^{\text {th }}$-century book of pharmacy made by the physicians in the 'Aḍudi hospital in Baghdad, based on the pharmacological work of physician Sābūr Ibn Sahl (d. 255/869), explains that "if a woman drinks some of the testicle and the rennet of a hare, she will be blessed with a male child." 403

Treatments of infertility sometimes also reflect the influence of particular conception theories. The "two-seed" theory of conception, which posited that women secrete a semen-like seed, implied a therapeutic corollary: to increase

396 Ullmann, Islamic Medicine, 109 and Medizin im Islam, 253.

397 al-Ṭabarī, Firdaws al-hikma fĩ al-țibb, 281.

398 On the history of the buduh magic square, including its obstetrical uses see, V. Porter, L. Saif, and E. Savage-Smith "Amulets, Magic, and Talismans" in Companion to Islamic Art and Architecture (Wiley-Blackwell, 2017), 538.

399 Ibn Sīnā, Qānūn fī al-țibb, 2:566 = kitāb III: fann 21: maqāla 1: al-tadbīr wa'l-'ilāj. 400 Ibn Sīnā, Qānūn fì al-țibb, 2:566 = kitāb III: fann 21: maqāla 1: al-tadbīr wa'l-'ilāj. 401 L. Chipman, The World of Pharmacy and Pharmacists in Mamluk Cairo (Leiden: Brill, 2010), 262. Al-Rāzī too recommends it for the same purpose. Al-Hāāwī, 9:58. Cf. al-Majūsī, al-Kāmil, 2:436.

402 This is one of only three ingredients which Dioscorides recommends to aid conception, but it is also a contraceptive. He writes that rabbit rennet "aids conception, but if drunk after menstruation, it causes barrenness.” Translation from J. Riddle, Goddesses, Elixirs, and Witches: Plants and Sexuality throughout Human History (New York: Palgrave Macmillan, 2010), 69.

403 Ibn Sahl and O. Kahl, Sābūr Ibn Sahl's Dispensatory in the Recension of the 'Adudì Hospital (Leiden: Brill, 2009), 210. 
the likelihood of conception, women ought to be stimulated so as to secrete more seed, and therefore husbands should make efforts to become more satisfying lovers. Ibn Sīnā advises:

There is no shame for the physician if he speaks about enlarging the penis, narrowing the entrance, and female sexual pleasure, because these two things occasion the production of offspring. Often, a small penis becomes a concern because the woman cannot be pleasured by it and so she does not ejaculate. Since she does not ejaculate there is no child. It may also become a concern because it might alienate his wife and she might seek someone other than him. Likewise, if she is not narrow, her husband will not satisfy her and she too will not satisfy her husband, and this must all be offset. Similarly, sexual pleasure encourages quick ejaculation, and in most cases of women whose ejaculation is delayed, and who are left with their desire unsatisfied, there is no offspring. ${ }^{404}$

In this way Ibn Sīnā argues that a physician may need to discuss sexual matters or recommend sexually enhancing alterations, in order to protect against infertility, as well as concupiscence.

The second theory of conception is sometimes called the "seed and soil" model. According to this theory, male sperm constitutes the only or main gamete, and the role of the female body is to serve as a space to grow and nourish the embryo. This image is found in the Greek tradition, including in Hippocratic writings, and seems to have coexisted with the two-seed theory of conception. This same is true in Ayurvedic texts such as the Charaka Samhita. ${ }^{405}$ The two coexist in the Islamic tradition as well. An example of reproductive organs being compared to a tilled field can be the found in the Qur'ān, in a passage frequently cited in legal discussions of intercourse. "Your women are a tillage for you; so come unto your tillage as you wish" (Q. 2:223). A similar image is evoked by the hadith, cited previously, "Beware of the barren woman, for one married to her is like a man ensconced at the top of a well, who waters his land daily, but whose land does not bloom, the stream [of water] is not absorbed. ${ }^{406}$

The classicist Ann Ellis Hanson has argued that this "seed and soil" model is also reflected in the practice of treating infertile women with fertilizer-like substances. Such methods of treatment are prevalent in Greek medicine and are closely associated with gynecology. For example, the following recipe comes from the Hippocratic text, Diseases of Women I:

404 Ibn Sīnā, Qānūn fĩ al-țibb, 2:549-50 = Kitāb III: Fann 20: maqāla 1: faṣl fī ‘udhr al-țabīb fī mā yu'allim min al-taldhïdh.

405 P. Rây and H.N. Gupta. Caraka Samhita; A Scientific Synopsis (New Delhi: National Institute of Sciences of India, 1965), 7-8.

406 Ibn Ḥabīb, Kitāb adab al-nisā’ al-mawsūm bi-kitāb al-ghāya wa’l-nihāya, 152-3. 


\begin{abstract}
If the mouth <of the womb> is closed, let her apply fig juice until it opens; and let her wash herself immediately with water. And crush hawk's excrement in sweet wine and give to drink whilst she is fasting, and let her immediately sleep with her husband. Or, whenever the menses are stopping, crush excrement of the Egyptian goose in rose perfume, and anoint the vagina and let her sleep with her husband. ${ }^{407}$
\end{abstract}

The fig juice has symbolic associations with fertility and the excrement used in this recipe has literal use as agricultural fertilizer. In the Hippocractic corpus, mention of dreckapotheke ("dung therapy") is limited to gynecological texts. ${ }^{408}$ In Arabic texts, the use of dung is not limited exclusively to gynecological and fertility-related matters, but it is particularly pronounced in those areas.

\title{
The intersection of infertility with other gynecological concerns
}

Female infertility is depicted in medieval medical texts as the potential consequence, or byproduct, of several other gynecological conditions and concerns, concerns which are also of great interest to physicians for reasons other than infertility. As a result, discussions of infertility also veer off into several other distinct, but intersecting, medical areas. These include the ascertainment of fetal sex and development, diagnosis of menstrual retention and uterine suffocation, and assessment of male and female reproductive history and prospects.

An example of these intersecting discussions can be seen in the continuation of a passage from the Firdaws al-hikma on the damage inflicted on the seed by excessive heat and cold. Al-Ṭabarī writes:

\begin{abstract}
Hippocrates says, if the breasts of pregnant women shrivel, they miscarry. If one breast shrivels, she miscarries the fetus which is on the side of the shriveled breast. If the color of the woman is good, that indicates that the fetus is male. If her color is ugly it indicates that the fetus is female. ${ }^{409}$ The reason for [Hippocrates'] statement is that the male is warm and the female is cold, and warmth improves coloring whereas cold makes it uglier and greener. ${ }^{410}$
\end{abstract}

Here we see the influence of the Hippocratic notion of the connection between the breasts and the bifurcated uterus, onto which has been mapped the Aristotelian concept that the male fetus is warmer (thereby providing healthier color-

407 This translation is from Hippocratic Recipes, 213.

408 Ibid., 212.

409 Hippocrates, Aphorisms, V. 38.

410 al-Ṭabarī, Firdaws al-ḥikma, 37. Cf. al-Baladī, Tadbīr al-ḥabālā, 18. 
ing) and the female is colder (producing a sickly color in the mother). The discussion of infertility and the proper environment for the seed moves into a discussion of miscarriage which is intermixed with a discussion of fetal sex diagnosis. Conception, pregnancy, and sex differences are all part of the same continuum of concerns and even the same continuum of diagnosis. We see this even among physicians with substantial disagreements as to the causes of sex variation, ${ }^{411}$ and even among those who express skepticism about the connection between heat and gender. This continuum of infertility and fetal sex diagnoses is articulated by al-Rāzì, accompanied by his characteristic caveats. In his experience, many men and women do not conform to humoral type.

Signs of conception: Apollonius said: if the menses are retained without fever or trembling or shortness [of breath] then she is pregnant. For menses which are retained due to illness present with the above [symptoms], but if the uterus shows no [sign of illness] then she is indeed pregnant. If she is pregnant with a male, then her color is good; if with a female then her color is pallid in comparison to her usual color prior to conception, for the female is colder while the male is warmer. This is so only in general, for it is possible for someone pregnant with a female [fetus] to improve her regimen after conception thus improving her color, and the opposite is possible too. There are many other signs of a male [fetus], such as having many and forceful movements. These signs are also only general ones, for if she is carrying a very weak male or a tremendously strong female one it is possible that [the female fetus's] movements will be greater and more forceful. [Galen?] said: the fetus cannot be cold unless both the sperm of the man and the uterus of the mother are cold at the same time. But as for me [al-Rāzī], I consider this to be ridiculous because it arbitrarily assigns categories for nature's actions . . . but we have indeed seen many women with humoral temperaments that are warmer than are those of many men. This indicates masculinity and femininity are not determined by warmth but rather by predominance of one type [of seed]. ${ }^{412}$

Al-Rāzì combines into a single discussion what might seem to the modern reader to be entirely separate topics: recognizing and differentiating between amenorrhea due to pregnancy and amenorrhea due to illness, differentiating between healthy pregnancy and unhealthy pregnancy, and differentiating between pregnancy with a male fetus from pregnancy with a female fetus.

411 See S. Gadelrab, "Discourses on Sex Differences in Medieval Scholarly Islamic Thought," Journal of the History of Medicine and Allied Sciences 66 (2011), 40-81 and N. Fancy, "Womb Heat versus Sperm Heat: Hippocrates against Galen and Ibn Sīnā in Ibn al-Nafīs's Commentaries," $150-175$.

412 al-Rāzī, al-Ḥāwī fì al-țibb, vol. 3, bk. 9:50 -1. Cf. Al-Baladī, Tadbīr al-ḥabālà', 20. 


\section{Menstrual retention and hysterical suffocation}

Menstruation and the qualities of menstrual blood occupy a central role in medieval discussions of both fertility in particular, and women's health in general. With regard to fertility, the significance of menstruation is two-fold. First, menstrual blood itself is understood to be either a female gamete or the source of nourishment for a fetus. Insufficient menstrual blood can also mean that the body lacks nourishment for the fetus. ${ }^{413}$ Second, menstrual blood is also understood as potentially blocking conception or rendering the environment of the uterus noxious if it is not flushed out correctly and regularly.

Infertility is not, however, the only problematic consequence of irregular menstruation. Rather, the medieval physicians continue the tradition of emphasizing the importance of menstruation to women's general health. They also continue to warn of the danger of retained menses and the disease known as "uterine suffocation." However, whereas Hippocratic descriptions of these illnesses pathologize the bodies of women who are not fulfilling the socially expected roles of marrying and producing children, and the treatments of these diseases appear to coerce women into fulfilling socially-approved roles, this is less true in medieval Arabo-Galenic discussions of these conditions.

$5^{\text {th }}$-century B.C. Greek texts describe uterine suffocation, also known as "hysterical suffocation," or "the wandering womb," as a disease in which the uterus expands or moves and in so doing displaces or crushes a woman's other vital organs, potentially causing a variety of dire symptoms, including insanity, epileptic-like fits and deathly faints. ${ }^{414}$ The phenomenon is famously described in Plato's Timaeus:

The seed [semen in males] having life, and becoming endowed with respiration, produces in that part in which it respires a lively desire of emission, and thus creates in us the love of procreation. Wherefore also in men the organ of generation becoming rebellious and masterful, like an animal disobedient to reason, and maddened with the sting of lust, seeks to gain absolute sway; and the same is the case with the so-called womb or matrix of women; the animal within them is desirous of procreating children, and when remaining unfruitful long beyond its proper time, gets discontented and angry, and wandering in every direction through the body, closes up the passages of the breath, and, by obstructing respiration,

413 Ibn Sīnā, Qānūn fī al-țibb, 2:567-71 = kitāb III: fann 21: maqāla 1.

414 The phenomenon of the "wandering womb" has received a great deal of scholarly attention. See, for example, C. Faraone, "The Rise of the Demon Womb in Greco-Roman Antiquity," in M. Parca and A. Tzanetou (eds.), Finding Persephone: Women's Rituals in the Ancient Mediterranean (Bloomington: Indiana University Press, 2007), 224-37; and S. Gilman et al., Hysteria Beyond Freud (Berkeley: University of California Press, 1993). 
drives them to extremity, causing all varieties of disease, until at length the desire and love of the man and the woman, bringing them together and as it were plucking the fruit from the tree, sow in the womb, as in a field, animals unseen by reason of their smallness and without form; these again are separated and matured within; they are then finally brought out into the light, and thus the generation of animals is completed. ${ }^{415}$

This description of sexual reproduction attributes to the uterus an independent "lust" equivalent to the "disobedient" lust subsisting in the male genitals. But the uterus diverges from its male counterpart by attacking its "host" when it is discontented by lack of children. It wanders up into the woman's body thereby suffocating her. In an effort to pacify it, man and woman engage in sexual intercourse. Implicit in this physiology is a message that women who do not engage in sexual intercourse and reproduction put themselves in mortal danger.

The Hippocratic treatise Diseases of Women I, describes hysterical suffocation thus:

When the womb is near the liver and the abdomen and when it is suffocating, the woman turns up the whites of her eyes and becomes chilled; some women become livid. She grinds her teeth and saliva flows out of her mouth. These women resemble those who suffer from Herakles' disease. ${ }^{416}$ If the womb lingers near the liver and the abdomen, the woman dies of the suffocation. ${ }^{417}$

The ultimate cure for hysterical suffocation is pregnancy, which weighs down the womb and keeps it from moving into other parts of the body. Sexual intercourse also helps because the moisture and weight provided by semen anchor the womb in place. Alternatively, sweet smelling substances can be applied to the vagina to "lure" the "animal" uterus down to its proper place, and foul-smelling substances can be applied to the nose to repel the uterus away from the upper body cavities. This last treatment is based on the previously mentioned premise that the mouth, uterus, and vagina are all part of one continuous channel.

In Aristotle's thought and in later Greek and Roman medicine, uterine suffocation continues to be an accepted diagnosis despite the widespread acknowledgement that the uterus is anchored in place by ligaments and so cannot

415 Timaeus 91b-d. Translation by B. Jowett. Galen's synopsis of the Timaeus was available in Arabic and there may have been other sources as well. On the Arabic reception of the Timaeus, see A. Das, "Galen and the Arabic traditions of Plato's Timaeus" (Ph.D. thesis: University of Warwick, 2013). For the reception of this specific passage see also, Weisser, Zeugung, Vererbung, und pränatale Entwicklung, 146-7.

416 I.e., epilepsy.

417 Translation in A. E. Hanson, "Hippocrates: 'Diseases of Women 1,"” §10. 
move into the regions occupied by other organs. ${ }^{418}$ Such knowledge was confirmed by human dissections undertaken in Alexandria in the generations after Aristotle's death. ${ }^{419}$ By the second century, Soranus and Galen are well aware that the uterus is moored in place by tissue connecting it to other organs with the result that it cannot wander. Soranus rejects the notion that the uterus can move upward and mocks the idea that the uterus possesses olfactory capabilities. But he does not reject the existence of the disease that was thought to be caused by the womb's wandering, claiming instead that inflamed ligaments pull the uterus in the wrong direction, thereby triggering the symptoms known as uterine suffocation. Moreover, although he entirely rejects the notion that the uterus is an animal-like being with a sense of smell, he still prescribes the same use of smells as therapy, on the grounds that they make the uterus contract. ${ }^{420}$

Galen too objects to the idea that the uterus can wander upward and yet he too takes for granted the existence of the condition described as uterine suffocation. ${ }^{421}$ He says that it occurs when retained menses and female seed rot, which in turn causes congestion in the blood vessels entering the uterus, which in turn distends the adjacent ligaments, which in turn pulls on the uterus such that the uterus rises, expands, or twists. Furthermore, the rotting of the retained menses creates a noxious fluid which poisons and chills the woman's whole body, thereby causing the severe symptoms. He attributes this disease particularly to widows and prescribes odor therapy as well as measures to "release" the build-up of female "semen." 422 Moreover, although as an anatomist Galen was well aware of the impossibility of hysterical suffocation, as a therapist he, as Monica Green puts it, "displayed his medical conservatism by retaining the odoriferous therapy even though, with his new etiology, it would have lost any semblance of a rational basis." ${ }^{223}$ Galen prescribes the use of both cupping and the application of strong smelling substances to the mouth and vagina to treat a woman whose

418 Aristotle, Generation of Animals 720a, 12-14, denies the wandering womb phenomenon. Aristotle, History of Animals 582b, 22-6, nonetheless says that an empty womb can rise upwards and cause suffocation.

419 C. Faraone, "Magical and Medical Approaches to the Wandering Womb in the Ancient Greek World.” Classical Antiquity 30 (2011):6.

420 H. King, Hippocrates' Woman: Reading the Female Body in Ancient Greece (London: Routledge, 1998), 231.

421 Galen, On the Usefulness of the Parts of the Body, tr. Margaret Tallmadge May (Ithaca: Cornell University Press, 1968), 2:653.

422 See Green, 'The Transmission of Ancient Theories of Female Physiology and Disease' 48. Also Helen King, 'Galen and the widow: towards a history of therapeutic masturbation in ancient gynaecology.' EuGeStA: Journal on Gender Studies in Antiquity 1 (2011): 205-235.

423 Green, "The Transmission of Ancient Theories of Female Physiology," 50. 
"uterus rises or experiences deviations." Like the Hippocratics, he appears to subscribe to the notion that sweet smells attract the uterus to its proper place and fetid smells repel it from its current abnormal place. We thus see in Soranus' and Galen's writings that the anatomical premise has changed drastically, since they know the uterus cannot sense smell, nor is it free to float about, much less to roam about the body like an animal desiring to satisfy its cravings. But the symptomology of the illness previously thought to be caused by the uterus moving does not change, only its etiology. Moreover, even though the etiology changes, the therapies, including odor therapy, do not change.

In medieval Arabic texts, the causes and cures for ikhtināq al-rahim (uterine suffocation/strangulation) are subtly reinterpreted in significant ways. Whereas in the Hippocratic texts both menstrual retention and hysterical suffocation are described as resulting from a person's status as a virgin, widow, or barren woman, over time, particularly in the Byzantine and Islamic periods, these conditions become attributed to a wider variety of causes, and suggested treatments varied just as widely. Al-Ṭabarī writes:

Retention of menses may be due to heat, dryness, severe fatigue, or nosebleed because this diminishes the blood, or [it may occur in] one who is fat for her blood departs due to her fat, or because the veins of her womb are narrow, or from a rupture. As a result of retention of the menses or lack of coitus, there may occur vapors, asthma, damage to the liver and stomach, heart palpitations, vile thoughts, headache, uterine suffocation, inability to conceive, abscess, and dropsy, because when the [uterus] retains the menstrual blood, [the blood] will coagulate in its veins and disperse its vapors into the entire body, thereby causing these maladies. ${ }^{424}$ Sometimes the uterus is stretched by a tumor or coagulated, sticky superfluities, such that it inclines to one side and is therefore lacking in height or width. Sometimes the uterus rises upwards towards the diaphragm thereby causing suffocation, and it overcomes the woman such that she may lose consciousness. In which case, a wool flake should be placed on her nose so as to learn whether she is alive or dead. If the wool moves, then she is alive. The cause of this is either an excess of coitus or the lack of it. For, if there is much seed it might rot and become like a poison, and sometimes it spreads and so the diaphragm convulses and the woman suffocates ... Sometimes an itch accompanied by swelling also occurs in the uterus due to the intensity of desire for sexual intercourse, just as in a male there is an itch and swelling due to desire. ${ }^{425}$

Much of al-Ṭabarī's above description has Greek antecedents. We see the Galenic assimilation of uterine suffocation into the framework of retained menses. The use of a flake of wool to ascertain whether a woman is still breathing, having lost consciousness as a result of a uterine ailment, comes from an anecdote

424 Cf. Bos, Ibn al-Jazzār on Sexual Diseases and Their Treatment, 264.

425 al-Ṭabarī, Firdaws al-ḥikma fì al-țibb, 273-5. 
found in several different Galenic texts. It is also found in Aetius of Amida's gynecological treatise. ${ }^{426}$ In some versions the woman is described as a longtime widow, but al-Tabarī makes no reference to the marital status of the unconscious woman here. ${ }^{427}$ As in the Timaeus, the uterus is depicted as swelling with sexual desire, comparable to male tumescence. Like Galen, al-Ṭabarī describes excessive female seed as needing to be removed, or exorcised. Menstrual blood needs to be exorcised as well, and he does not clearly differentiate between menses and seed. The menses or seed can potentially endanger a woman if they are not evacuated and instead coagulate and rot. When it putrefies it makes the uterus uninhabitable for any embryo and sends vapors or fumes throughout the rest of the body, especially upwards towards the head. This retained menstrual blood or seed may indeed be attributed to a woman's failure to engage in sexual relations with a man, but al-Tabarī also suggests it can be attributed to the woman engaging in too much sexual activity. (The notion that sexual excess causes hysterical suffocation can also be found in the works of pre-Islamic authors as well, such as Paul of Aegina and Aetius, who writes that it is most prevalent among lascivious women and those who make use of contraceptive drugs. ${ }^{428}$ ) Furthermore, al-Tabarī also believes that these maladies can also be attributed to a host of other problems, some psycho-social (such as shock or depression) and others more physical, such as cold or hemorrhoids. ${ }^{429}$

The extent to which these conditions are associated with unattached women varies somewhat in medieval medical texts. Ibn al-Jazzār, like al-Ṭabarī, conflates hysterical suffocation (which he very much associates with sexual deprivation) with menstrual retention, which he does not particularly associate with sexual deprivation. He writes:

[Hysterical suffocation] occurs [to a woman] by reason of a surplus and corruption of her sperm when she is withheld from sexual intercourse. For then the sperm increases, corrupts and becomes like a poison. This happens mostly to widows, especially when they have

426 Aetius of Amida, The Gynaecology and Obstetrics of the VIth century, 70.

427 The story of Galen's use of wool to test whether a sexually-deprived widow has fainted or died is found in several sources, including Galen, On the Usefulness of the Parts, K. VIII, 414-15. It appears to have entered into the Arabic corpus via Paul of Aegina, appearing in al-Rāzī, Ibn alJazzār, and Ibn Sīnā’s works. For interpretations of this anecdote see Helen King, 'Galen and the widow: towards a history of therapeutic masturbation in ancient gynaecology.' EuGeStA: Journal on Gender Studies in Antiquity 1 (2011), 205-235.

428 S. Gilman et al., Hysteria Beyond Freud. (Berkeley: University of California Press, 1993), 47. 429 Cf. al-Rāzī, al- Ḥāwì fì al-țibb, 9:37. Cf. Ibn Sīnā, Qānūn fì al-țibb, 2:600 = kitāb III: fann 21: maqāla 4:'alāmāt (ikhtināq al-raḥim). 
given birth to many children. It can also happen to women when they have reached sexual maturity without knowing any man. For when the sperm has collected in them, they need its emission just like men, which is a natural act. But when the woman does not have a man, the sperm is collected in her and a cold vapour arises from it to the respiratory diaphragm because of its connection to the uterus. This causes asthma, and because the diaphragm is connected with the throat and with the places of [origin] of the voice suffocation occurs to her, as we have explained. This disease can also be caused by retention of the menstruation, for when the retained menstrual blood and the sperm collect in them, the disease called "hysterical suffocation" occurs to them with extreme force, especially in autumn or in winter. ${ }^{430}$

Here hysterical suffocation is identified as particularly prevalent among unattached women, not because the uterus is searching for reproduction, but because both sexes require sexual release in order to be healthy, lest "cold vapors" arise from the retained male and female sperm. ${ }^{431}$ It can also occur due to the lack of evacuation of the menses. ${ }^{432}$ The diseases at hand are more prevalent among adult virgins and widows, according to Ibn al-Jazzār, but despite many pages of detailed instructions as to how to alleviate the problem, neither he nor al-Tabarī recommend that the problem be fixed through marriage. This is also true of Paul of Aegina and Aetius of Amida's treatment of the subject. ${ }^{433}$ In other words, hysterical suffocation and menstrual retention are diagnoses that no longer necessarily serve to pathologize unattached women.

This is also somewhat true of al-Rāzì's pronouncements on the topic. The exception can be found in his treatise dedicated to enumerating the medical virtues of sexual activity, in which he describes it as a potential cure for hysterical suffocation. ${ }^{434}$ He also quotes other people's opinions about the medical value of intercourse for treating these conditions. In his $H \bar{a} w \bar{\imath}$, he lists a dozen different authorities, citing both their descriptions of hysterical suffocation and their cures for it, and among them he cites the opinions of older authorities who do recommend marriage for curing the malady. There he quotes Hippocrates as saying "if she does not have a husband then one marries her off quickly" 435 and "this suffocation does not occur to pregnant women. Therefore my [recommendation] is

430 Bos, Ibn al-Jazzār on Sexual Diseases and Their Treatment, 274-275. Bos' translation. 431 Cf. Ibn al-Quff.

432 See also Ibn Sīnā, Qānūn fĩ al-țibb 2:589 = Kitāb 3: fann 21: maqāla 3: faṣl fĩ a'rāọ [ihtibās altamth]

433 See Green, "The Transmission if Ancient Theories of Female Physiology and Disease," 106. 434 Peter E. Pormann. "Al-Rāzī (d. 925) on the Benefits of Sex: A Clinician Caught between Philosophy and Medicine." $O$ ye gentlemen: Arabic studies on science and literary culture, in honour of Remke Kruk 2 (2007), 124

435 al-Rāzī, al-Ḥāwī, 9:43. 
that it is treated with what brings down the blood and thins out the semen, or with much sexual intercourse . . . If she becomes pregnant, the situation is obviated altogether, for the womb is weighed down and moves back and is made moist." ${ }^{436}$ He also cites al-Masīh's commentary on Diseases of Young Girls, "When a woman matures to the point of menstruation and is a virgin, blood is diverted toward her uterus . . . and it causes something like insanity in her. If that has happened, it [?] should be removed and then one should marry her off, for if she becomes pregnant she will become healthy." ${ }^{437}$

Both Ibn Sīnā and al-Majūsī explicitly recommend marriage if the patient is a virgin. Al-Majūsī writes, "If the woman is a virgin, then she must marry. If she rarely engages in intercourse, she should do so. For intercourse voids the semen which is retained in its passages and unblocks the blockage which was caused by it['s retention] and, in so doing, makes it cease, God willing." 438 If the cause of hysterical suffocation is found to be "retention of semen," Ibn Sīnā recommends marriage as one possible cure. Note that the assumption in this case is that the woman is not currently engaging in sexual relations because she is unmarried. Thus it appears that the "semen" in this case is female semen, which has not found an outlet.

If the cause of the [hysterical suffocation] is retention of the semen, then it is necessary to get started on marriage. Until that time, she should engage in exercise and [make use of] those things which dry out the semen, such as rue, mint ... . as in the [aforementioned] recipe. The midwife must insert her hand in the vagina and rub it with oil of lily or nard or laurel, and massage the entrance to the vagina, and she should massage the entrance to the uterus a great deal. [The patient] must be given both pleasure and pain, so that it will be like the experience of sexual intercourse..$^{439}$

Although Ibn Sīnā encourages marriage to cure hysterical suffocation, unlike in the Hippocratic texts, marriage is not recommended for the purpose of curing the woman's wandering womb by weighing it down with pregnancy or with male

436 Ibid., 9:44.

437 Ibid., 9:45. This is ‘'̄sā b. Ḥakam al-Dimashqī, known as al-Masīḥ. Ibn Abī 'Ușaybi‘a says he lived during the time of Harūn al-Rashīd. Ibn Abī 'Ușaybi'a does not mention him having written this treatise. He is referred to extensively by al-Baladī in Tadbìr al-ḥabālā'.

438 al-Majūsī, al-Kāmil, 2:438-9.

439 Ibn Sīnā, Qānūn fĩ al-țibb 2:602 = Kitāb 3: Fann 21: maqāla 4: faṣl fĩ al-mu'ālajāt. Cf. Ibn Sīnā, Qānūn fì al-țibb, 2:599 = Kitāb III: fann 21: maqāla 4: faṣl fī ikhtināq al-rahimim. The phrase is reminiscent of Galen's On the Affected Places. For an analysis of the history of the interpretation of this passage in modern scholarship see H. King, "Galen and the widow: towards a history of therapeutic masturbation in ancient gynaecology.” EuGeStA: Journal on Gender Studies in Antiquity 1 (2011), 203-235. 
semen. Rather, it is recommended to give her the opportunity to rid herself of her own pent-up female semen. The alternative he offers appears to be medical masturbation as a means of evacuating female semen in much the same way that men do. (Some of the language here, including the reference to "pleasure and pain" is reminiscent of the language of Galen and the widow.)

In other medieval texts, the potential causes of menstrual retention and hysterical suffocation are so numerous and varied that the diagnoses no longer function as a means of reinforcing particular gender roles. Rather the diagnoses serve as an intermediary step, providing a rational basis for linking almost any precipitating factor with a treatment which promises cleansing, purgation, relaxation, or release. Ibn al-Jazzār, for example, writes that retained menses can be caused by nosebleeds, hemorrhoids, excessive fat, exercise, sorrow, fear, anxiety, and anger. The symptoms of menstrual retention are similarly non-specific. It can manifest in the form of emaciation, nausea, fever, and lack of sexual appetite. ${ }^{440}$ As for treatment options, Ibn al-Jazzār recommends several different ways to evacuate or exorcise the retained blood, fumigation being the preferred technique. Other therapies include pessaries, back and foot massage, rubbing the genitals (performed by a midwife), ${ }^{441}$ bleeding, and cupping. ${ }^{442} \mathrm{All}$ of these techniques involve the creation of intimate and sensory-rich experiences, the purpose of which is to effect a form of release and relief by breaking down and expelling whatever is frustrating the normal menstrual and reproductive cycle.

One can see the cross-over appeal of such a diagnosis. It can be understood in strictly biological terms - the blood is being blocked in the uterus and, as a result, is undergoing a natural process of decay and so it must be evacuated and the uterus cleaned of the rot by means of incense burning and intimate touch to break down or remove the decay. But it can just as easily fit into worldviews that posit that a woman can be inhabited by a malevolent force, a ghost twin, or an evil eye, which must be released, driven out, or exorcised so that the body can resume its normal functions, possibly by means of rituals involving strong scents and intimate touch. Christopher Faraone has demonstrated that, in the Roman and Byzantine worlds, there was a great deal of intellectual compatibility of medical understandings of the wandering womb and magical concepts exhibited in material culture. Amulets and magical recipe books have been found from the first, second, and fourth centuries (the most recent, from

440 Bos, Ibn al-Jazzār, 263-4.

441 Ibn Sīnā makes the same suggestion, op. cit. al-Rāzī does so as well and quotes previous authorities for doing so in al-Hāà fì al-țibb, 9:38, 40 and 44. al-Majūsī also writes that the midwives do this, see al-Kämil, 2:428.

442 Bos, Ibn al-Jazzār, 275. Cf. al-Rāzì, al-Ḥāwī, 41 and 44. 
Upper Egypt) which abjure the womb itself to stay in place, and both of these accord with the demonic exorcism practices of the time. ${ }^{443}$ It may be argued that echoes of this notion can be seen in modern Egyptian fertility rituals as described by Marcia Inhorn and others. ${ }^{444}$

\section{Childless couples and the assessment of each spouse's fertility}

\section{Acknowledgement of male-factor infertility}

Throughout the Arabo-Galenic medical corpus, male-factor infertility, femalefactor infertility, and "incompatibility" between the humoral temperaments of a couple are all recognized as potential reasons for a woman to fail to become pregnant. Male infertility receives somewhat more attention in the Arabic tradition than in the Greek, though still not nearly to the extent of female infertility. Male infertility is generally attributed to one of three failings: humoral imbalance, producing too little sperm, and erectile difficulties. Some authors also claim that male infertility can be caused by defective sperm or by a problem with the angle of the penis such that it cannot project semen "in a straight line." ${ }^{445}$ However, the inability on the part of the man to produce offspring is rarely classified as a disease to be treated in and of itself in medical encyclopedias. Rather, male infertility is addressed as a subsection of discussions about undesirable sexual performance. Often male infertility is conflated with impotence, small penis size, and lack of sexual prowess. The is less true in Ibn Sinnā's Qānūn where, in several places, male and female infertility are described in similar terms and addressed at the same time. ${ }^{446}$ There the terminology for male and female fertility-related difficulties is so similar that it is sometimes difficult to tell which partner is under discussion. Ibn Sīnā repeatedly uses the term

443 Faraone, "Magical and Medical Approaches to the Wandering Womb in the Ancient Greek World." 19-22.

444 M. Inhorn, Quest for Conception, xxiii; R. Natvig, "Liminal Rites and Female Symbolism in the Egyptian Zar Possession Cult," Numen 35 (1988), 57-68; and J. Boddy, Wombs and Alien Spirits: Women, Men, and the Zar Cult in Northern Sudan (Madison: University of Wisconsin Press, 1986).

445 Țabarī, Firdaws al-ḥikma, 37-38. Cf. Philip J. van der Eijk, Diocles of Carystus. (Leiden: Brill, 2001), 1:87-91 and 2:93-97.

446 Ibn Sīnā, Qānūn fì al-țibb, 2:562 = kitāb III: fann 21: maqāla 1: faṣl fī dalā’il al-yabūsa. 
manī to refer to both men's and women's "sperm," ${ }^{447}$ by which he means male semen and, it seems, female ejaculate. Another, unusual expression of egalitarianism with respect to male and female infertility can be found in al-Majūsì's brief discussion of the topic. While other physicians prescribe surgical treatments for female infertility, in his Kämil al-Majūsī does the same with respect to male infertility: "If instead [his infertility] is due to a blockage within the vesicles of the penis, then he must be treated by unblocking that blockage by using a blade, which we will discuss in the chapter on surgery." 448

One reason the diagnosis of sterility and fertility in men received comparatively little attention in medical texts is due to the fact that men who wanted to prove themselves fertile even if they failed to conceive with their spouses had ample opportunity to do so, whereas women did not. In a society where divorce, polygamy, and concubinage were options, a man could potentially have multiple sexual partners, and thus multiple opportunities to attempt to procreate. Ibn Sīnā makes a point similar to Aristotle's about the inegalitarianism of medicine in this regard: while a husband may be medically advised to have sexual relations with another woman, such is not the case with respect to a wife. He writes:

Regarding the infertile [woman] and sterile [man] by nature: a person with a humoral temperament contrary to that of his partner needs to replace them. As for a person with a short penis, there is no remedy. Similarly, [there is no remedy for] a woman whose orifice for menstruating has become plugged up as a result of ulcers which have since healed over and become slippery. Regarding a woman who needs to replace her husband, the physician is not in a position to help her. But regarding the rest of the cases, there are [treatments]. ${ }^{449}$

In other words, for husbands with a "incompatible" sexual partner, a physician might medically advise him to take on a new one. (We have encountered physicians offering help in choosing sexual partners for their male patients in al-Rāzì, Kitāb Shukūk 'alā Jālīnūs, and his contemporary al-Ruhāwī mentions something similar. ${ }^{450}$ ) It is socially unacceptable for physicians to offer such advice to women who are having difficulty conceiving with their husbands. Like Aristotle and Ibn Sīnā, al-Majūsī too suggests that a man's apparent sterility might simply be due to incompatibility, and so it is appropriate for the physician to recommend that the man attempt to procreate with someone new.

447 Ibn Sīnā, Qānūn fī al-țibb, 2:562 = kitāb III: fann 21: maqāla 1: faṣl fī al-'uqr wa-'usr al-ḥabl 448 al-Majūsī, Kāmil al-șinā'a fì al-țibb, 2:437.

449 Ibn Sīnā, Qānūn fì al-țibb, 2:565 = kitāb III:fann 21: maqāla 1: al-tadbìr wa’l-'ilāj. My italics. 450 E.g. al-Rāzī, Kitāb Shukūk 'alā Jālīnūs, 79 and al-Ruhāwì’s Adab al-țabīb, in Levey, 'Medical Ethics of Medieval Islam,' 90. 
If lack of conception is due to the husband, and that is due to his sperm having little compatibility with some women, then he must switch women so that he may encounter what will be compatible with the humoral temperament of his sperm..$^{451}$

Since medieval authors acknowledge that childlessness could be a result of either incompatibility or a difficulty subsisting in either the man or woman, naturally the medical literature includes many tests of assessing individual fertility and infertility. Some tests assess both partners simultaneously, while others test only the woman for fertility. In the Arabic medical corpus these diagnostic measures appear to be employed only after a woman has failed to conceive, rather than to distinguish fertile from infertile women prior to marriage. To my knowledge, these texts do not suggest a standard amount of time that should elapse before medical attention is sought.

One commonly described means of establishing whether the male or female partner in a sexual relationship is responsible for that union's childlessness is by examining the qualities of their urine. Al-Ṭabarī writes:

If the woman does not produce children, and you want to know whether that is due to the woman or due to the man, then take some of the man's urine and sprinkle it on a growing lettuce root, and sprinkle the urine of the woman on another lettuce root. ${ }^{452}$ The next day whichever root is found to have dried up, then that seed is the corrupt one. ${ }^{453}$ Or take some of both their seeds and put them [this likely refers to the lettuce upon which each has urinated] in a vessel in which there is water, and whichever of the seeds floats to the surface of the water, that is the one in which there is infertility and corruption. Or take some peas, lentils and beans, and plant them in the ground, and have woman urinate on them for two days. If any of them germinate as a result, then she can conceive. And if not, then she cannot. ${ }^{454}$

Such urine tests seem to be common across a wide variety of cultures and appear in ancient medical and magical texts throughout the Mediterranean world. ${ }^{455}$ In-

451 al-Majūsī, Kāmil al-șinā‘a fī al-țibb, 2:437.

452 Cf. Ibn Sīnā, Qānūn fĩ al-țibb, 2:564 = Kitāb III: Fann 21: maqāla 1: faṣl fī al-'alāmāat ['alāmāt al-'uqr].

453 Like the garlic test, this too will become a tool for diagnosing virginity (though only on the part of women). E.g., whereas in the Greek texts this is either a pregnancy or a fertility test, in the Sefer ahavat nashim the author maintains "The sages of Greece do this experiment: the girl must urinate over marshmallows in the evening, and bring them in the morning; if they are still fresh she is modest and good, if not, she is not." Caballero-Navas, Book of Women's Love, 142. 454 al-Ṭabarī, Fïrdaws al-ḥikma fì al-țibb, 38.

455 For an attempt to draw a direct connection between ancient Egyptian versions of this test and late medieval Egyptian versions, see A. Bayoumi, "Survivances Egyptiennes," Bulletin de la Société royale de géographie d’Égypte 19 (1937): 279-287. 
terestingly, what is tested is not the parents' gametes, but rather a broader quality of being nurturing versus poisonous that subsists even in urine. Such a test is particularly adaptable because it does not require that one subscribe to any particular theory about what constitutes the female contribution to the embryo.

\section{The garlic test: A case study of recapitulated tradition and innovation}

Among the many procedures for diagnosing fertility is one that stands out both for its longevity and for the perspective it can offer us on the transmission and reinterpretation of ancient medical heritages. The test appears in a wide variety of medieval Arabic-language literary genres, including medical compendia, obstetrical treatises, erotica, slave-buying guides, and encyclopedias. It also appears in other languages and eras, spanning three continents and 3000 years. It can be found in some of the oldest Egyptian medical papyri, Hippocratic gynecological treatises, the writings of the Roman and Byzantine physicians, the Babylonian Talmud, and in medieval Hebrew and Latin texts up through the early modern period.

The procedure appears in a number of variations within the Hippocratic corpus.

If a woman does not conceive, and you wish to ascertain whether she can conceive, having wrapped her up in blankets, fumigate below, and if it appears that the scent passes through the body to the nostrils and mouth, know that of herself she is not unfruitful. ${ }^{456}$

Test for fertility: boil a head of garlic and apply it to the uterus; on the next day have the woman examine herself by palpating with a finger; and if her mouth smells, the sign is positive. If not, make another application.

Test for fertility: enclose a little oil of bitter almonds in a piece of wool, apply it [as a vaginal suppository], and see what the woman's mouth smells of. ${ }^{457}$

Apply a suppository of a little oil of bitter almonds wrapped in wool: then at dawn examine whether the suppository has given off an odor through the woman's mouth: if it has, she will become pregnant, but otherwise not . . . Another: thoroughly clean a head of garlic, snip it off, and apply as a suppository against the uterus: on the following day, see whether it has given off an odor through the woman's mouth: if it has, she will become pregnant, but otherwise not. ${ }^{458}$

456 Hippocrates, Aphorisms 5:59. Translation by Francis Adams. Slightly modified.

457 Hippocrates, Nature of Woman, §96. Translation by Paul Potter. Hippocrates Vol. X (Cambridge, MA: Harvard University Press, 2012), 303.

458 Hippocrates On Barrenness, §214. Translation by Paul Potter. Hippocrates Vol. X, 339-40. 
In each of these iterations of the test a strongly smelling substance is inserted into the woman's vagina. If the odor penetrates from the woman's vagina up through her mouth it means that she can indeed conceive, and therefore she should not be blamed for a couple's lack of conception. Moreover, another Hippocratic treatise, Superfetation, describing a rather different version of the test, mentions that if one were to administer it to a currently pregnant woman the smell would not penetrate. ${ }^{459}$

Very similar tests can also be found in two, much older, Egyptian medical papyri. Nearly a century ago Erik Iversen identified the similarities between the Hippocratic passages and the Carlsberg VIII papyrus (likely dating from the $13^{\text {th }}$ century B.C. but possibly reflecting a $19^{\text {th }}$-century B.C. text) and the Kahun medical papyrus \#28 (dating from c. 1800 B.C.). Iversen viewed them as evidence of the direct influence of Egyptian medicine on Greek medicine. The Egyptian texts read:

To determine who will <bear children> and who will not <bear children>, you should then cause the bulb of an onion to spend the night in her flesh until dawn. If the odor appears in her mouth, she will bear <children $>$. If $<$ it does not $>$, she will never <bear children $>\ldots{ }^{460}$

Another method. Leave overnight a clove of garlic moistened (with . . . ) in the body (i.e. in the vagina). If you smell garlic on her breath, she will give birth (normally). If you cannot smell it, she will not give birth normally, and this will always be the case. ${ }^{461}$

The two tests described in the Egyptian texts are indeed similar to each other and to the Hippocratic ones - a clove of onion or garlic is placed in the woman's vagina, she sleeps on it overnight, and the next day she is inspected to see if the smell is exhaled from her mouth - but the condition being tested in the second instance is somewhat ambiguous. It may be a form of fertility test ${ }^{462}$ or it may be, as Jacques Jouanna understands it, a test to predict whether a currently existing pregnancy will eventually be followed with healthy birth. ${ }^{463}$ If it is a test of the

459 Hippocrates, Superfetation $\S 25$.

460 Papyrus Carlsberg 8. 4 = Kahun Medical Papyrus 28. Quoted in Totelin, Hippocratic Recipes, 181. Iversen's transcription of the papyrus appears in E. Iversen, "Papyrus Carlsberg VIII with some remarks on the Egyptian origin of some popular birth prognoses," Det. Kgl. Danske Videnskabernes Selskab. Historisk-filologiske Meddelelser XXVI (1939), 21-22.

461 J. Jouanna, Greek Medicine from Hippocrates to Galen (Leiden: Brill, 2012), 5.

462 Strouhal, Evžen, Břetislav Vachala, and Hana Vymazalová. The Medicine of the Ancient Egyptians. 1, Surgery, Gynecology, Obstetrics, and Pediatrics. 162 Strouhal, Evžen, Břetislav Vachala, and Hana Vymazalová. The Medicine of the Ancient Egyptians. Vol. 1, Surgery, Gynecology, Obstetrics, and Pediatrics (Cairo: American University in Cairo Press, 2014) 162

463 He concludes, contra Iversen, "Thus it is difficult to speak of direct influence." Ibid., 5-6. 
health of a pregnancy, then it reflects an understanding of female anatomy that is somewhat at odds with the one found in the Hippocratic gynecological text Superfetation, which claims that a pregnant woman should not be permeable to smells from substances inserted into the vagina. However, in both the Egyptian and Greek version of the garlic test, an unblocked passage is a desirable finding indicating the fertility of the woman or the health of her current pregnancy, while obstruction is indicative of ill-health.

Between the Hippocratic period and the dawn of Islam, the procedure continued to be described in medical literature as a fertility test. In his Gynecology, Soranus attests that it was used by his predecessors Diocles, Euenor, and Euryphon, though he himself does not subscribe to the underlying physiology behind the test since he believes that that it can provide a false negative test for infertility. ${ }^{464}$ (These misgivings are suppressed in later texts that claim Soranus as an authority. For example, the $6^{\text {th }}$-century Byzantine physician Aetius of Amida appears to suggest that Soranus subscribes to the efficacy of the test. ${ }^{465}$ ) Galen, unlike Soranus, does not directly challenge the reliability of the garlic test. Instead, in his commentary on Aphorisms 5.59, he overlays the test with a humoral significance. ${ }^{466}$ According to Galen, if the odor does not permeate up to the woman's mouth it means that the womb and the pathways in the body are clogged, and they are clogged due to an excess of cold or moisture. This clogged state can be rectified by introducing hot, cold, moist, or dry substances to change the humoral balance, thereby restoring fertility. Galen thereby maintains the test but offers a modified interpretation as to how it works. The same is true of Stephanus of Athens's (fl. late- $6^{\text {th }} /$ early- $7^{\text {th }}$-century) line of reasoning in his lectures on Aphorisms. Stephanus seems to only half-heartedly subscribe to the science underlying the test. He does not refer to a single physical channel which must remain unblocked but rather to a more generalized sense of healthy sympathy and communication by means of "the veins, arteries and nerves." Nonetheless, he understands the test to be meaningful. ${ }^{467}$

Despite these differences in explaining why the test works, until the $3^{\text {rd }} /$ $9^{\text {th }}$ century there does not seem to be any substantial change in the understanding of what the garlic test demonstrates: the transfer of the smell of garlic from

464 Soranus, Gynecology, 33-4.

465 Aetius of Amida, The Gynaecology and Obstetrics of the VIth century, tr. James Ricci (Philadelphia: Blakiston, 1950), 19.

466 Galen, and K.G. Kühn. Clavdii Galeni Opera Omnia. (Lipsiae: prostat in officina libraria C. Cnoblochii, 1821-1833), 17: 857.

467 Stephanus, and Leendert Gerrit Westerink, Commentary On Hippocrates' Aphorisms (Berlin: Akademie-Verlag, 1985) 160-161. 
the vagina to the mouth indicates that a woman will be able to conceive. (There is one possible exception, mentioned in two places in the Talmud, which will be addressed below. ${ }^{468}$ ) This changes with the medieval iterations of the garlic test. In the Firdaws al-hikma, al-Ṭabarī extensively and accurately quotes the Hippocratic texts up until he reaches the garlic test:

[Hippocrates] also said, "If you want to know if a woman will conceive or not, then sit her on a pierced chair, cover her with a robe, and fumigate her from beneath with costus or sandarac, or aloeswood, and if you find the smell ${ }^{469}$ of the incense [emerging] from her nostrils, then she will conceive. If not, then she will not conceive. ${ }^{470}$ The reason for [Hippocrates'] statement is that if the smell does not emerge from the nose, that is indicative that the body's passages and the uterus are damaged.

He also said that if a woman drinks mixed honey [hydromel] before sleeping not having eaten, and then she experiences colic around her middle, then she is pregnant. ${ }^{471}$ And if not, then she is not. The reason for this statement of his is that the uterus, if it is occupied with a seed, is closed up. Mixed honey provokes bloating and if the womb is closed up, the passage for the wind is narrowed, and this bloating is retained in the [womb] thereby provoking colic. Another person said a woman should place garlic in her vagina and sleep on it, and if the next day there is a smell of garlic then she is pregnant. And if not, then there is no pregnancy in her. ${ }^{472}$

Most of this passage is taken almost verbatim from Hippocratic texts and Galen's commentary on the Aphorisms. However, in the last sentence, there is a significant departure from the older texts. In the Firdaws al-hikma, the incense-based

468 See Talmud Bavli Ketubot 10b and Talmud Bavli, Yevamot 60b.

469 Alternatively: "if the smell is found."

470 Cf. Hippocrates' Aphorisms 5:59: "If a woman does not conceive and wishes to ascertain whether she can conceive, having wrapped her up in blankets, fumigate below and, if it appears that the scent passes through the body to the nostrils and mouth, know that of herself she is not unfruitful." Translation by Francis Adams.

471 Cf. Hippocrates' Aphorisms 5:41: "If you wish to ascertain if a woman be with child, give her mixed honey to drink when she is going to sleep, and has not taken supper, and if she be seized with colic in the belly, she is with child, but otherwise she is not pregnant." Translation, slightly modified, from Francis Adams. Cf. al-Rāzī, al-Ḥāwī fì al-ṭibb, vol. 3, bk 9:50.

472 al-Ṭabarī, Firdaws al-hikma fì al-țibb, 37-38. Siggel translates this into German as "so kann sie empfangen ... so kann sie nicht empfangen," i.e., she can conceive. Given the context of the paragraph, and the grammar of the sentence, I do not think an unmodified reading of the Arabic supports this interpretation. From the context, it appears that this is a test of pregnancy, not a test of potential fertility. See A. Siggel, "Gynäkologie, Embryologie und Frauenhygiene aus dem Paradies der Weisheit über die Medizin des Abū al-Ḥasan 'Alī b. Sahl Rabbān at-Ṭabarī,” Quellen und Studien zur Geschichte Naturwissenschaften und der Medizin 8 (1941), 238. Weisser appears to read al-Ṭabarī's sentence as I do, see Weisser, Zeugung, Vererbung, und pränatale Entwicklung, 159. 
version of the procedure diagnoses fertility, but that is not the case when the test is done with garlic. Instead, al-Ṭabarī describes it as a test of whether or not conception has occurred. It is a pregnancy test. Al-Tabari does not seem to feel the need to explain why the emergence of the garlic smell from the mouth of a woman is evidence of her pregnancy. It does not necessarily follow from the initial concept (which he has not discarded) of fertility being dependent on unblocked passages. It does, however, accord with ancient Egyptian texts, and it makes sense if we understand his logic to be that the smell of the garlic on her breath constitutes a desirable outcome irrespective of whether one is testing for fertility or pregnancy.

In Arabic medical texts dating from the next three centuries, we continue to find this procedure described as a test either for fertility or for pregnancy or both, with three different interpretations of what the outcome of the test means. These interpretations are (1) the presence of the scent in her mouth is indicative of fertility, (2) it is indicative of pregnancy, or (3) it is indicative of lack of current pregnancy. In the $4^{\text {th }} / 10^{\text {th }}$ century, the garlic-as-fertility-test is mentioned by al-Rāzīis in Iraq in his al-Hẫwi fĩ al-țibb, and by Aḥmad al-Baladī in Egypt in his obstetrical text. ${ }^{474}$ By contrast, an obstetrical text produced in Spain during the same period by 'Arīb b. Sa'īd al-Qurțubī describes the garlic-based version of the procedure as a pregnancy test and the incense-based version as a fertility test, just as al-Tabarī does. Al-Qurțubī writes, "if the next day the scent of the garlic emerges from the nose, it is a sign of conception. If it does not do so, then she is not pregnant." ${ }^{475}$ This is particularly curious because, in the paragraph immediately preceding this one, al-Qurtubi says that a sign of pregnancy is that the mouth of the uterus is closed over. In theory, such a closing of the cervix would interrupt the passage between the vagina and the mouth. One would thus expect that the transfer of the garlic odor from vagina to mouth would be an indication that the cervix was still open and that pregnancy had not occurred. However, alQurtubi does not appear to be consistent in this regard.

Ibn Sīnā's Qānūn describes the garlic test twice, once as a test for fertility or lack thereof, and once as a test for pregnancy or lack thereof but, unlike alTabarī and al-Qurțubī, his anatomical theory remains consistent and accords more closely with Hippocratic thought. In his section on the signs of infertility Ibn Sinnā, like the Hippocratics, writes that the presence of the smell indicates

473 Cf. Al-Rāzī, al-Ḥāwī fĩ al-ṭibb, vol. 3, book 9:52.

474 Al-Baladī, Tadbīr al-habāàlā', 18.

475 'Arīb ibn Sa'īd al-Qurțubī, Kitāb khalq al-janīn wa-tadbīr al-ḥabālā wa'l-mawlūdīn = La livre de la génération du foetus et le traitement des femmes enceintes et des nouveau-nés (Algiers: Librairie Ferraris, 1956), 28. 
an unobstructed path and hence a prospect of fertility. ${ }^{476}$ The test then appears three pages later as a pregnancy test, but the pregnancy is proven absent by the smell of garlic in a woman's mouth. He writes:

Conception can be diagnosed through tests. Among them is having the woman drink two waqitas of Sara-check before sleep, or similarly mixed rainwater, and then seeing whether there is colic or not, because in conjunction these cause retention and bloating in the intestines. Physicians are convinced by this, and it is a positive test, except for those women who are already accustomed to drinking this. Another [test]: she should submit to a fast for a day and then in the evening be wrapped in robes and fumigate herself on a pierced chair with a cone of incense. If the fumes and smell emerge from her mouth and nose, then there is no conception in her. A similar negative test is taking garlic, sleeping on it, and [seeing] if the smell and taste of it is in her mouth or not. ${ }^{477}$

Here the anatomical premise is maintained, i.e. the premise that normally the path from the vagina to the uterus to the mouth is unobstructed, and the existence of an obstruction indicates that either the cervix has closed, as occurs during pregnancy, or there is something in the uterus causing a blockage, i.e. a fetus. What has changed is that finding the path to be unobstructed is no longer necessarily a desirable outcome. The presence of garlic in the mouth is an indication that pregnancy has failed to be achieved.

In slave-buying guides, the procedure appears as a pregnancy test, but with two opposing interpretations. In the Risāla fī shirā al-raqīq wa-taqlīb al-'abìd by the $5^{\text {th }} / 11^{\text {th }}$-century Baghdadi Christian physician Ibn Buṭān, the author writes about women being sold as slaves. The slave dealer attempts to conceal the fact that they are pregnant by displaying fake menstrual blood.

What conceals pregnancy: the slaver provides the slave woman with fake blood to display, made from resin and dragon's blood ${ }^{478}$ - if she cannot obtain the blood of animals.

To verify the existence of a pregnancy and its health: This knowledge can be obtained by placing beneath the woman incense such as ambergris, and preventing [the smell] from exiting from the sides or openings in her robes. If the smell issues from her mouth, then she is not pregnant. And the opposite [is true too]. ${ }^{479}$

476 Ibn Sīnā, Qānūn fì al-țibb 2:564 = kitāb III: fann 21: maqāla 1: faṣl fì al-'alāmāt ['alāmāt al'uqr].

477 Ibn Sīnā, Qānūn fī al-țibb 2:567 = kitāb III: fann 21: maqāla 1: faṣl fī 'alāmāt al-ḥabl waahkāmihi.

478 I.e. a red dye made from plant resin or cinnabar.

479 Ibn Buṭlān, Risāla fī shirā al-raqīq wa-taqlīb al-'abīd, 383. I am grateful to Dr. Hannah Barker for drawing my attention to this passage and the subsequent one. 
This accords with Ibn Sīnā's view. More than a century later and on a different continent, Ibn Buṭlān's advice appears again, in al-Andalus, in a market-inspector's manual by al-Saqatī from c. 606/1210. Much of al-Saqatī's advice in the surrounding passages is a precis of Ibn Buṭlān's advice, except for his interpretation of this test: he understands it as having the opposite meaning from the one attributed to it by his source.

They [masculine plural] conceal pregnancy by displaying fake blood, manufactured from resin and dragon's blood, if no animal blood is obtainable. One can become informed [male singular] about the pregnancy of a woman by placing below her incense or ambergris and preventing it from exiting via her sleeves or garments. If the smell issues from her mouth, then she is pregnant. And if it does not, then she is not pregnant. ${ }^{480}$

It is noteworthy that the two Andalusians, al-Saqati (the $6^{\text {th }} / 12^{\text {th }}$-century author of the market inspector's manual) and al-Qurțubi (the $4^{\text {th }} / 10^{\text {th }}$-century author of the obstetrical treatise) interpret the test in the same way, i.e. that the permeation of the smell is a positive sign of pregnancy.

By the $7^{\text {th }} / 13^{\text {th }}$-century, we encounter a new iteration of the test with another set of permutations about its interpretation. In his Kitāb 'ajā'ib al-makhlūqāt wa'l-hayawānāt wa-gharā'ib al-mawjūdāt (Book of The Wonders of Creation and the Peculiarities of Beings) the Persian cosmographer al-Qazwīnī (d. 682/ 1283) explains the test as follows. "If you want to know whether a woman is a virgin or a non-virgin then mix thinly sliced garlic with honey and tell her to carry it [in her vagina], and then wait two hours. If the odor of the garlic can be smelled from her mouth then she is a virgin, if not then she is a non-virgin." ${ }^{481}$ Here once again the permeation of the smell is positive sign, but now it does not indicate fertility, or pregnancy, but rather virginity.

Such an interpretation might seem counterintuitive, given that discussions of female virginity tend to presuppose the existence of a physical barrier in the form of a hymen. We might assume that the garlic test could more logically test for virginity by determining hymenal intactness. Under such circumstances, a finding of a garlic smell in a woman's mouth ought to be indicative of the loss of virginity, whereas the lack of smell would indicate that the hymenal obstruction is still in place. Indeed, that is precisely what we find in an Egyptian encyclopedia produced one generation later. The author, Shihāb al-Dīn Ahmad al-Nu-

480 Al-Saqatī, Fī adāb al-ḥisba = Un manuel hispanique de Hisba, 52.

481 Al-Qazwīnī, 'Ajā’ỉb al-makhlūqāt wa-al-ḥayawānāt wa-gharā’ib al-mawjūdāt (Beirut: Mu'assasat al-A'lamī li’l-Mațbū‘āt, 2000), 231. 
wayrī (d. 733/1333) writes that the procedure can be used as a virginity test, as a pregnancy test, and as a fertility test.

\begin{abstract}
Ḥunayn ibn Ishāq said ${ }^{482}$ : If you want to know if a woman is a virgin or non-virgin have her take peeled garlic and insert it and carry it in her vagina overnight. When she wakes up let her breath out, and if the smell of the garlic is in her mouth then she is a non-virgin. But if [the smell] is not present in her mouth then she is a virgin.

So too one may recognize her pregnancy: if the smell of garlic is present then she is not pregnant, and if it is not present then she is pregnant.

If you want to find out the state of woman, whether she may yet become pregnant or not, then have her take rolled birthwort and crush it with the gall of a cow, then have her keep it in overnight. If the next morning its smell is found in her mouth, then she may become pregnant. And if not, then she is infertile. ${ }^{483}$
\end{abstract}

Thus, according to al-Nuwayrī, an obstruction indicates either virginity or pregnancy or sterility, whereas the presence of a smell indicates sexual experience, lack of pregnancy, or fertility. The same virginity test, in slightly different words and without the attribution to Ibn Ishāq is also found in the therapeutic work Kanz al-ikhtiṣāṣ by 'Izz al-Dīn ibn Aydamar al-Jaldakī, an $8^{\text {th }} / 14^{\text {th }}$-century Persian alchemist and physician who traveled as far as Yemen and North Africa. This same passage (without the attribution to Hunayn ibn Ishāa) is also quoted in Rạ̣ma fì al-țibb wa'l-ḥikma, by the famed Islamic scholar Jalāl al-Dīn alSuyūṭi (d. 911/1505), in the context of a chapter on restoring virginity to the non-virgin. The description of the garlic test is immediately followed by several recipes for pessaries that restore virginity. ${ }^{484}$

Such formulations, in which both virginity and pregnancy are proven by a lack of smell, continued to be repeated in later Middle Eastern literature. But this is not to suggest that the older interpretations of the garlic test were abandoned. The famous book of erotic medicine by Ibn Kamal Pasha (d. 941/1534) Rujū' al-shaykh ila șibāh (The Return of the Old Man to His Youth) describes the garlic-based version of the test as a means of establishing pregnancy and recommends the incense version of the test to establish fertility and infertility. Ibn Kamal Pasha's interpretation of the garlic test is similar to that of al-Tabarī, alQurțubì, and al-Saqatî: if the scent of garlic permeates to her mouth then she is pregnant.

482 I have been unable to locate this quotation in the works of Ḥunayn ibn Ishāa.

483 al-Nuwayrī, Nihāyat al-arab fī funūn al-adab (Beirut: Dār al-Kutub al-'Ilmiyya, 2004), 12:129. Italics are mine.

484 Jalāl al-Dīn al-Suyūṭī, Kitāb al-Raḥma fĩ al- țibb wa’l-ḥikma (Beirut: Dār al-Arqam, 2011), 182 (chapter 136). 
Beyond the Islamic world too, the garlic test was the subject of these permutations, with new ones introduced. A particularly interesting version can be found in a $13^{\text {th }}$-century Hebrew gynecological text from southern Europe called Sefer ahavat nashim (The Book of Women's Love). The book recommends fumigating the uterus and, "if the smoke reaches her mouth and is bitter, she is not a virgin; if it does not, she is a virgin. You could do the same to a barren woman: if the smoke goes up to her mouth and is bitter, you will know that she is barren; if not, she is closed and not barren." ${ }^{85}$ This too is immediately followed by virginity-restoration recipes. At this point, it seems that the communication of smells from the vagina up to the mouth has become attached to undesirable results, i.e. lack of virginity, and so, by association, it becomes attached to another undesirable outcome, i.e. infertility. So, in this case, the test has the exact opposite diagnostic value of the one articulated in the Hippocratic texts, despite sharing the same gynecological premises.

The history of the garlic test has much to teach us about the nature of medieval learned gynecology. First, the garlic test is an example of an idea whose origins are ambiguous. Its medieval versions clearly reference Greek formulations, but the underlying concept may also be indigenous to parts of the Middle East, present before the translation movement of the early 'Abbasid period. After all, the garlic test is found even in ancient Egypt, where it was connected with pregnancy rather than fertility. Second, the garlic test suggests some degree of correlation between "book medicine" and medical practice. The very fact that the uses attributed to the garlic test vary, but do so all within one specific theoretical framework, suggests that the garlic test was an actual procedure, not merely an intellectual exercise. By contrast, unvaried and non-specific descriptions of procedures are indicative of their having never been actually implemented, as Emilie Savage-Smith has argued in reference to other medical procedures. ${ }^{486}$

The garlic test also serves to remind us of the basic problems and solutions available to the would-be medieval gynecologist. The basic problem was that women's genitals were internal and hidden, and thus it was difficult to know whether all was well or if something was wrong with respect to fertility, pregnancy, or virginity. One solution to this problem was to posit that one can discover what is happening inside the body by supposing that the internal organs are

485 Caballero-Navas, Book of Women's Love, 142. On the history and derivation of medieval Jewish gynecological texts see R. Barkaï, Les infortunes de Dinah, le livre de la génération: La gynécologie juive au Moyen âge (Paris: Cerf, 1991).

486 Emilie Savage-Smith, “The Practice of Surgery in Islamic Lands: Myth and Reality,” Social History of Medicine 13 (2000), 307-321. 
connected to the outside, visible world and by mapping what is happening at the entries and exits of the body. The garlic test, and the fumigations too, thus function like an x-ray or sonogram. The modern physician learns about that which is in the body by bombarding the body with electro-magnetic radiation or soundwaves and creates a picture based upon what penetrates the body and what does not. The medieval physician did so using scents.

The garlic test is also significant because it highlights the connections between the diagnosis of women's bodies, blame, and social control. The test invites us to think about certain gynecological practices as not merely medical diagnostic tools but rather as women's rituals. The garlic test is a performance, or ordeal, whose specific meaning is subject to interpretive variation, but whose purpose remains constant. In all its permutations it has a consistent goal: to scientifically uncover the "facts" about a woman's sexual past or her reproductive future, facts which in the present are always in doubt. The test is predicated on the notion that her unknown past and future are possible to discover because they leave a tangible mark on her present body. We might therefore be inclined to view infertility testing, like virginity testing, as a tool of patriarchal intimidation. It threatens women by perpetuating the notion that their bodies can be checked to if they are fit or defective. However, there is another way of interpreting such tests.

In some of the Hebrew and Arabic versions of the procedure as virginity test, the procedure is immediately followed by advice about how to restore or fake virginity. In these contexts, therefore, the garlic test is one of a set of tools to be utilized by a woman to avert blame from herself.

The utility of such a test as a means of defending a woman and restoring her to her husband's good graces is illustrated dramatically in a version found in Babylonian Talmud, from a passage likely originating in the $3^{\text {rd }}$-century. This version uses not garlic, or incense, but the fumes from a barrel of wine. The test appears in a one of a series of anecdotes, in each of which a groom after the wedding comes before a rabbi and voices his suspicions that his bride was not a virgin. In each case the rabbi to whom the groom brings his concern provides either a theoretical explanation or an empirical test which would account for the lack of appearance of virginity despite the bride being a virgin at the time of consummation. Each anecdote concludes with a recommendation to the groom that he consider himself fortunate and "go enjoy she whom you have acquired."

A man came before Rabban Gamliel the son of Rabbi [Yehudah Ha-Nasi] and said to him: My master, I engaged in intercourse and did not find blood. She [the bride] said to him: My master, I am still a virgin. 
[Rabban Gamliel] said to them: Bring me two maidservants, one a virgin and one a non-virgin. They brought them to him and he seated them on the opening of a cask of wine. The scent of the [wine] wafted through the non-virgin but the scent of it did not waft through the virgin. He then seated the [wife] on the cask, and the scent of it did not waft through. [Rabban Gamliel] said to the [husband]: Go enjoy she whom you have acquired.

Why did [Rabban Gamliel] not just initially examine [the bride] by this [method]? Because he had heard of [the theory] but had never seen it in practice. And he thought that perhaps it is not certain, and it is not proper to subject Jewish women to indignities needlessly. ${ }^{487}$

This story depicts the test as undignified but ultimately useful in supporting the woman's claims. In the Aphorisms too, the fertility test is depicted as a means of proving that a couple's childlessness is not the woman's fault, and Stephanus of Athens suggests that its purpose is to coerce the husband rather than the wife. In other words, the test might not have been wielded primarily as a weapon against women. Rather it might have been a defensive tool, by means of which a woman could attempt to exonerate herself from accusations of fault, and blunt the force of a man's distrust, by "scientifically" assuaging his doubts. The garlic test, like virginity restoration, might well have offered women a shield to fend off patriarchal judgement and condemnation.

487 Talmud Bavli Ketubot 10b. 